\title{
Effects of peripartal yeast culture supplementation on lactation performance, blood biomarkers, rumen fermentation, and rumen bacteria species in dairy cows
}

\author{
N. A. Carpinelli, ${ }^{1} \odot$ J. Halfen, ${ }^{1,2} \odot$ E. Trevisi, ${ }^{3} \odot$ J. D. Chapman, ${ }^{4} \odot$ E. D. Sharman, ${ }^{4} \odot$ J. L. Anderson, ${ }^{1} \odot$ \\ and J. S. Osorio ${ }^{1 *}$ \\ ${ }^{1}$ Department of Dairy and Food Sciences, South Dakota State University, Brookings 57007 \\ ${ }^{2}$ Núcleo de Pesquisa, Ensino e Extenssão em Pecuária, Universidade Federal de Pelotas, Pelotas, Rio Grande do Sul, Brazil 96010610 \\ ${ }^{3}$ Department of Animal Sciences, Food and Nutrition (DIANA), Facoltà di Scienze Agrarie, Alimentari e Ambientali, \\ Università Cattolica del Sacro Cuore, 29122 Piacenza, Italy \\ ${ }^{4}$ Phibro Animal Health, Teaneck, NJ 07666
}

\section{ABSTRACT}

Feeding yeast culture fermentation products has been associated with improved feed intake and milk yield in transition dairy cows. These improvements in performance have been further described in terms of rumen characteristics, metabolic profile, and immune response. The objective of this study was to evaluate the effects of a commercial yeast culture product (YC; Culture Classic HD, Phibro Animal Health) on performance, blood biomarkers, rumen fermentation, and rumen bacterial population in dairy cows from -30 to $50 \mathrm{~d}$ in milk (DIM). Forty Holstein dairy cows were enrolled in a randomized complete block design from -30 to 50 DIM and blocked according to expected calving day, parity, previous milk yield, and genetic merit. At -30 DIM, cows were assigned to either a basal diet plus $114 \mathrm{~g} / \mathrm{d}$ of ground corn (control; $\mathrm{n}=20$ ) or a basal diet plus $100 \mathrm{~g} / \mathrm{d}$ of ground corn and $14 \mathrm{~g} / \mathrm{d}$ of $\mathrm{YC}(\mathrm{n}=$ 20), fed as a top-dress. Cows received the same close-up diet from $30 \mathrm{~d}$ prepartum until calving $[1.39 \mathrm{Mcal} / \mathrm{kg}$ of dry matter (DM) and $12.3 \%$ crude protein $(\mathrm{CP})]$ and lactation diet from calving to 50 DIM $(1.60 \mathrm{Mcal} / \mathrm{kg}$ of $\mathrm{DM}$ and $15.6 \% \mathrm{CP}$ ). Blood samples and rumen fluid were collected at various time points from -30 to $50 \mathrm{~d}$ relative to calving. Cows fed YC compared with control showed a trend for increased energy-corrected milk $(+3.2 \mathrm{~kg} / \mathrm{d})$. Lower somatic cell counts were observed in $\mathrm{YC}$ cows than in control. We detected a treatment $\times$ time interaction in nonesterified fatty acids (NEFA) that could be attributed to a trend for greater NEFA

Received December 7, 2020.

Accepted May 24, 2021.

*Corresponding author: Johan.Osorio@sdstate.edu in $\mathrm{YC}$ cows than control at 7 DIM, followed by lower NEFA in YC cows than control at 14 and 30 DIM. In the rumen, YC contributed to mild changes in rumen fermentation, mainly increasing postpartal valerate while decreasing prepartal isovalerate. This was accompanied by alterations in rumen microbiota, including a greater abundance of cellulolytic (Fibrobacter succinogenes) and lactate-utilizing bacteria (Megasphaera elsdenii). These results describe the potential benefits of supplementing yeast culture during the late pregnancy through early lactation, at least in terms of rumen environment and performance.

Key words: transition cow, yeast culture, rumen bacteria

\section{INTRODUCTION}

The transition period has been defined by Drackley (1999) as a critical period for dairy cows, characterized between $3 \mathrm{wk}$ before and $3 \mathrm{wk}$ after parturition. This is a challenging period for dairy cows because of lactogenesis, uterine involution, as well as metabolic and endocrine changes associated with negative energy balance (NEB; Bradford et al., 2015), which often impairs the immune response (Trevisi and Minuti, 2018). The adverse effects of NEB, such as reduced feed intake, severe body fat mobilization, and production of reactive oxygen species, among others, can severely impair immune cell response (Trevisi and Minuti, 2018). Yeast products and yeast-containing feed ingredients can be used as a nutritional feed additive to improve health and performance during the transition between pregnancy and early lactation (Roche et al., 2013; Lopreiato et al., 2020).

Yeast culture is a complex fermentation product that contains yeast biomass and fermentation metabolites produced during specific fermentation process, includ- 
ing vitamins, peptides, AA, nucleotides, lipids, organic acids, oligosaccharides, esters, and alcohols (Jensen et al., 2008; Shurson, 2018). According to ChaucheyrasDurand et al. (2008), the main effects of yeast products are related to rumen fermentation, benefiting key microbial populations and their metabolism, and consequently increasing fiber degradation and stabilizing rumen $\mathrm{pH}$.

The beneficial effects of different live yeast or yeast culture-based products have been reported on the performance of dairy cows supplemented throughout the transition period or during early lactation only (Dann et al., 2000; Nocek et al., 2011; Shi et al., 2019a). These effects have been further described in terms of rumen characteristics (Al Ibrahim et al., 2010; Bach et al., 2019), metabolic profile (Zaworski et al., 2014; FaccioDemarco et al., 2019; Olagaray et al., 2019), and immune system function (Yuan et al., 2015b; Knoblock et al., 2019; Lopreiato et al., 2020). However, these cumulative data on yeast supplementation across transition cow studies are inconsistent and might be associated with the wide variety of configurations of yeast cultures or yeast fermentation metabolites used in such studies.

Live yeast supplementation during the transition period has been observed to have a greater influence in rumen microbiota prepartum than postpartum (Bach et al., 2019); the Streptococcus genus was the only one affected by live yeast postpartum (Bach et al., 2019). However, to the best of our knowledge, little is known about the effects of yeast culture supplementation during the transition period on ruminal bacteria species.

The yeast culture evaluated in the current study was a concentrated form of yeast, yeast components, and fermentation metabolites originating from a Saccharomyces cerevisiae yeast strain that is grown on a medium and dried on beneficial plant-based carriers. The hypothesis was that feeding this complex product during the transition period would affect performance and ruminal characteristics. The objective of this study was to evaluate the effects of this yeast culture product (Culture Classic HD; Phibro Animal Health) on performance, blood biomarkers, rumen fermentation, and ruminal bacteria population in dairy cows during the transition period until 50 DIM.

\section{MATERIALS AND METHODS}

\section{Experimental Design and Dietary Treatments}

The Institutional Animal Care and Use Committee of the South Dakota State University (Brookings, SD) approved all procedures for this study (protocol no. 18028A). A total of 43 prepartum Holstein dairy cows,
Table 1. Frequency of occurrence of health problems in peripartal dairy cows fed a basal diet (Control) or a basal diet supplemented with a yeast culture fermentation product $(\mathrm{YC})$ from $-31 \pm 6 \mathrm{~d}$ relative to calving through 50 DIM

\begin{tabular}{lcc}
\hline & \multicolumn{2}{c}{ Treatment } \\
\cline { 2 - 3 } Event & Control & YC \\
\hline Total & 22 & 21 \\
Ketosis $^{1}$ & 5 & 6 \\
Lameness $^{2}$ & 0 & 1 \\
Mastitis $^{3}$ & 0 & 3 \\
Metritis $^{4}$ & 0 & 1 \\
Retained placenta $^{5}$ & 1 & 4 \\
Total excluded cows $^{6}$ & 2 & 1 \\
\hline
\end{tabular}

${ }^{1}$ Defined as cows having $>1.4 \mathrm{mmol} / \mathrm{L}$ ketone concentration in blood, detected using a Precision Xtra analyzer (Abbott Labs). Treatment administrated was oral propylene glycol and injection of vitamin B complex.

${ }^{2}$ Defined as cows having locomotion score $>4$, diagnosed with clinical lameness.

${ }^{3}$ Determined based on the California Mastitis Test.

${ }^{4}$ Foul-smelling, watery-consistency uterine discharge after calving.

${ }^{5}$ Defined as fetal membranes retained $>24 \mathrm{~h}$ postpartum.

${ }^{6}$ Cows excluded due to calving with $<14 \mathrm{~d}$ on treatment diets $(\mathrm{n}=2)$ and twin calving $(\mathrm{n}=1)$.

including 35 multiparous and 8 primiparous cows, were used in a randomized complete block design and were blocked according to expected calving day, parity, and previous lactation milk yield $(11,498 \pm 2,328 \mathrm{~kg})$ for multiparous cows or genetic merit for primiparous. A total of 3 cows were removed from the experiment due to calving with $<14 \mathrm{~d}$ on treatments diets $(\mathrm{n}=2)$ and twin calving $(\mathrm{n}=1$; Table 1$)$. Cows received the same far-off diet until $-30 \mathrm{~d}$ before expected calving date. From $-30 \mathrm{~d}$ to parturition, cows received a basal closeup diet once a day $\left(1.39 \mathrm{Mcal}\right.$ of $\mathrm{NE}_{\mathrm{L}} / \mathrm{kg}$ and $12.3 \%$ $\mathrm{CP}$; Table 2). After calving, all cows received the basal lactation diet once a day $\left(1.60 \mathrm{Mcal}\right.$ of $\mathrm{NE}_{\mathrm{L}} / \mathrm{kg}$ and $15.6 \% \mathrm{CP}$; Table 2). Both diets were fed as a total mixed ration. At $-30 \mathrm{~d}$ before calving, cows were assigned to either a basal diet (control; $114 \mathrm{~g} / \mathrm{d}$ of ground corn; $\mathrm{n}=20$ ) or basal diet plus the Culture Classic HD yeast culture fermentation product (YC; $100 \mathrm{~g}$ of ground corn $+14 \mathrm{~g}$ of $\mathrm{YC} / \mathrm{d} ; \mathrm{n}=20)$. The treatments were top-dressed once a day from $-31 \pm 6$ to 50 DIM.

\section{Animal Management}

Cows were enrolled in the experiment from midSeptember 2018 to early April 2019. Cows were fed using an individual gate system (American Calan), and intakes were recorded daily. Diets were formulated using the Cornell Net Carbohydrate and Protein System model, contained in the NDS Professional ration formulation software (v. 6.55 ; RUM\&N) to meet require- 
Table 2. Ingredient composition of diets during the close-up ( $-31 \pm$ $6 \mathrm{~d}$ to calving) and early lactation periods

\begin{tabular}{|c|c|c|}
\hline \multirow[b]{2}{*}{ Component } & \multicolumn{2}{|c|}{ Diet } \\
\hline & Close-up & Lactation \\
\hline \multicolumn{3}{|l|}{ Ingredient, ${ }^{1} \%$ DMI } \\
\hline Corn silage & 37.6 & 36.31 \\
\hline Alfalfa silage & - & 8.71 \\
\hline Alfalfa hay & - & 15.97 \\
\hline Grass hay & 23.9 & - \\
\hline Cotton seed & - & 8.25 \\
\hline Wheat straw & 12.6 & - \\
\hline Soy best & 10.6 & - \\
\hline Corn grain ground fine & 3.9 & 16.07 \\
\hline Soybean meal & 4.67 & 3.65 \\
\hline Distillers grains dry & - & 3.66 \\
\hline Animate $^{2}$ & 3.15 & - \\
\hline Wheat middling & - & 3.65 \\
\hline Calcium carbonate & 2.36 & 1.00 \\
\hline Calcium phosphate Di & 0.47 & - \\
\hline Sodium bicarbonate & - & 0.91 \\
\hline Rumen-inert fat ${ }^{3}$ & - & 0.91 \\
\hline Salt white & 0.17 & 0.34 \\
\hline Magnesium oxide & 0.19 & 0.16 \\
\hline Urea & - & 0.11 \\
\hline JPW Dairy Vitamin Premix ${ }^{4}$ & 0.13 & 0.10 \\
\hline JPW Dairy TM Premix ${ }^{5}$ & 0.09 & 0.10 \\
\hline Rumen-protected $\mathrm{Met}^{6}$ & - & 0.04 \\
\hline Vitamin $\mathrm{E}^{7}$ & 0.16 & 0.04 \\
\hline Biotin $1 \%$ & - & 0.01 \\
\hline Monensin ${ }^{8}$ & 0.01 & 0.01 \\
\hline \multicolumn{3}{|l|}{ Chemical analysis } \\
\hline DM, $\%$ & 49.8 & 50.6 \\
\hline $\mathrm{NE}_{\mathrm{L}}, \mathrm{Mcal} / \mathrm{kg}$ of $\mathrm{DM}$ & 1.5 & 1.6 \\
\hline $\mathrm{CP}, \% \mathrm{DM}$ & 12.3 & 15.6 \\
\hline NDF, \% DM & 46.4 & 38.5 \\
\hline $\mathrm{ADF}, \% \mathrm{DM}$ & 28.8 & 25.8 \\
\hline $\mathrm{DCAD}, \mathrm{mEq} / 100 \mathrm{~g}$ & -9.7 & - \\
\hline
\end{tabular}

${ }^{1}$ Ingredients included in the ration formulated with NDS Professional (v. 6.55; RUM\&N) based on the Cornell Net Carbohydrate and Protein System model.

${ }^{2}$ Animate was used as the sole DCAD anion source.

${ }^{3}$ Energy Booster 100 (MSC).

${ }^{4}$ Contained $25.8 \% \mathrm{Ca}$ (DM basis) 1,545 IU $/ \mathrm{kg}$ of vitamin $\mathrm{A}, 387 \mathrm{IU} / \mathrm{kg}$ of vitamin $\mathrm{D}$, and $4,826 \mathrm{IU} / \mathrm{kg}$ of vitamin $\mathrm{E}$ (JPW Nutrition).

${ }^{5}$ Contained $11.7 \% \mathrm{Ca}$ (DM basis), $1.96 \% \mathrm{~S}, 10,527 \mathrm{mg} / \mathrm{kg}$ of Fe, 63,158 $\mathrm{mg} / \mathrm{kg}$ of Zn, $12,632 \mathrm{mg} / \mathrm{kg}$ of Cu, $63,158 \mathrm{mg} / \mathrm{kg}$ of Mn, $325 \mathrm{mg} / \mathrm{kg}$ of $\mathrm{Se}, 632 \mathrm{mg} / \mathrm{kg}$ of Co, and 1,053 mg/kg of I (JPW Nutrition).

${ }^{6}$ Mepron (Evonik Nutrition and Care $\mathrm{GmbH}$ ).

${ }^{7}$ Vitamin E, 9,090 IU/kg.

${ }^{8}$ Rumensin 90 (200 g of monensin in $1 \mathrm{~kg}$ of product; Elanco Animal Health).

ments of the average cow in the group according to the NRC (2001; Table 2). Dry matter content of individual feed ingredients was determined weekly, and diets were adjusted accordingly to maintain formulated DM ratios of ingredients in the TMR.

During the dry period, cows were housed in a beddedpack pen, and $3 \mathrm{~d}$ before expected calving date, cows were reallocated in individual pens bedded with straw until parturition. On d 3 postpartum, cows were moved to a lactation freestall barn, where they received the same lactation basal diet until $50 \mathrm{~d}$ postpartum.

Body weight was measured weekly for each cow in the afternoon at $1300 \mathrm{~h}$. Body condition score (scale $1=$ thin to $5=$ obese) was recorded weekly by 2 individuals, and the average score was used for statistical analysis.

\section{Feed and Milk Samples}

Individual samples of ingredients and TMR were collected weekly and frozen at $-20^{\circ} \mathrm{C}$ after $\mathrm{DM}$ analysis and until further nutrient profile analysis. Composited samples for ingredients and TMR were analyzed for contents of DM, CP, NDF, and ADF using wet chemistry methods, and $\mathrm{NE}_{\mathrm{L}}$ was calculated at a commercial laboratory (Dairy One, Ithaca, NY; https:// dairyone.com/download/forage-forage-lab-analytical -procedures/).

Cows were milked twice a day, and milk yield was recorded at each milking until 50 DIM. Consecutive morning and evening milk samples were collected $1 \mathrm{~d} /$ wk during the experimental period. Milk samples were composited in proportion to milk yield at each milking, preserved (Broad Spectrum Microtabs II, Advanced Instruments), and analyzed for fat, protein, lactose, solids, MUN, and SCC. The ECM was calculated based on milk yield and milk sample analysis as follows: ECM $=[12.82 \times$ fat yield $(\mathrm{kg})]+[7.13 \times$ protein yield $(\mathrm{kg})]$ $+[0.323 \times$ milk yield $(\mathrm{kg})]$ (Hutjens, 2010). Equations from the NRC (2001) were used to calculate both preand postpartum energy balance (EB) for each multiparous cow. The net energy intake $\left(\mathbf{N E}_{\mathbf{I}}\right)$ was determined using daily DMI multiplied by $\mathrm{NE}_{\mathrm{L}}$ density of the diet. Net energy for maintenance $\left(\mathrm{NE}_{\mathrm{M}}\right)$ was calculated as $\mathrm{BW}^{0.75} \times 0.080$. Requirements of $\mathrm{NE}_{\mathrm{L}}$ were calculated as $\mathrm{NE}_{\mathrm{L}}=(0.0929 \times$ fat $\%+0.0547 \times$ protein $\%+$ $0.0395 \times$ lactose $\%) \times$ milk yield. The net energy requirement for pregnancy $\left(\mathbf{N E}_{\mathbf{P}} ; \mathrm{Mcal} / \mathrm{d}\right)$ was calculated as $\mathrm{NE}_{\mathrm{P}}=[(0.00318 \times$ day of gestation -0.0352$)$ $\times$ (calf birth weight $/ 45)] / 0.218$. The equation used to calculate prepartal $\mathrm{EB}\left(\mathbf{E B}_{\mathrm{PRE}} ; \mathrm{Mcal} / \mathrm{d}\right)$ was $\mathrm{EB}_{\mathrm{PRE}}=$ $\mathrm{NE}_{\mathrm{I}}-\left(\mathrm{NE}_{\mathrm{M}}+\mathrm{NE}_{\mathrm{P}}\right)$ and $\mathrm{EB}_{\mathrm{PRE}}$ (as percent of requirements $)=\left[\mathrm{NE}_{\mathrm{I}} /\left(\mathrm{NE}_{\mathrm{M}}+\mathrm{NE}_{\mathrm{P}}\right)\right] \times 100$. The equation used to calculate postpartal EB ( EB $\left._{\text {POST }}\right)$ was EB $_{\text {POST }}$ $($ Mcal $/ \mathrm{d})=\mathrm{NE}_{\mathrm{I}}-\left(\mathrm{NE}_{\mathrm{M}}+\mathrm{NE}_{\mathrm{L}}\right)$ and $\mathrm{EB}_{\mathrm{POST}}$ (as percent of requirements $)=\left[\mathrm{NE}_{\mathrm{I}} /\left(\mathrm{NE}_{\mathrm{M}}+\mathrm{NE}_{\mathrm{L}}\right)\right] \times 100$.

For primiparous cows, the $\mathrm{NE}_{\mathrm{M}}, \mathrm{NE}_{\mathrm{P}}$, and $\mathrm{NE}_{\mathrm{L}}$ were calculated with the same equations used for multiparous cows. Additionally, net energy for gain $\left(\mathrm{NE}_{\mathrm{G}}\right)$ was calculated using Equation 11-2 from the NRC (2001). Data from the South Dakota State University Dairy Research and Training Facility (Brookings, SD) were 
used to obtain average age at first calving and an estimate of mature BW of multiparous cows in the herd. This information was used to estimate mature shrunk BW, target weight at first breeding, and target age of first pregnancy for primiparous cows. The expanded equation for calculation of retained energy was as follows:

$$
\begin{gathered}
\mathrm{NE}_{\mathrm{G}}=0.0635 \times\{0.891 \times[(0.96 \times \text { current } \mathrm{BW}) \\
\times(478 / \text { mature shrunk BW })]\}^{0.75} \\
\times\{0.956 \times[\text { target BW at first breeding } \\
\quad-(0.96 \times \text { current } \mathrm{BW})] /
\end{gathered}
$$

The following equation resulted after using the herd estimates, shown in bold:

$$
\begin{aligned}
& \mathrm{NE}_{\mathrm{G}}=0.0635 \times\{0.891 \times[(0.96 \times \text { current } \mathrm{BW}) \\
& \times(478 / \mathbf{6 8 5} \mathbf{~ k g})]\}^{0.75} \times\{0.956 \times[\mathbf{3 7 7} \mathbf{~ k g}-(0.96 \\
& \quad \times \text { current } \mathrm{BW})] /[\mathbf{4 4 9} \mathbf{d}-\text { current age }]\}^{1.097}
\end{aligned}
$$

Then, prepartal and postpartal EB for primiparous cows were calculated as $\mathrm{EB}_{\mathrm{PRE}}=\mathrm{NE}_{\mathrm{I}}-\left(\mathrm{NE}_{\mathrm{M}}+\mathrm{NE}_{\mathrm{P}}\right.$ $\left.+\mathrm{NE}_{\mathrm{G}}\right)$ and $\mathrm{EB}_{\mathrm{POST}}=\mathrm{NE}_{\mathrm{I}}-\left(\mathrm{NE}_{\mathrm{M}}+\mathrm{NE}_{\mathrm{L}}+\mathrm{NE}_{\mathrm{G}}\right)$, respectively.

\section{Blood Collection and Analyses}

Blood was sampled from the coccygeal vein before morning feeding using a 20-gauge Vacutainer needle (Becton Dickinson) at $-30,-15,7,14$, and $30 \mathrm{~d}$ relative to parturition from a subset of cows $(\mathrm{n}=8$ multiparous cows/treatment). Blood was collected into evacuated tubes (BD Vacutainer, Becton Dickinson) containing either serum clot activator or lithium heparin. After collection, tubes that contained lithium heparin were placed on ice, and tubes with serum clot activator were kept at $21^{\circ} \mathrm{C}$ until centrifugation $(\sim 30 \mathrm{~min})$. Serum and plasma were obtained by centrifugation at 1,300 $\times g$ for $15 \mathrm{~min}$ at $21^{\circ} \mathrm{C}$ and $4^{\circ} \mathrm{C}$, respectively. The aliquots of plasma were frozen at $-80^{\circ} \mathrm{C}$ until further analysis.

Plasma samples were analyzed for biomarkers of muscle body mass (i.e., creatinine and urea), metabolism [i.e., glucose, nonesterified fatty acids (NEFA), and $\mathrm{BHB}]$, and oxidative stress (i.e., reactive oxygen metabolites and ferric reducing antioxidant power) using kits purchased from Instrumentation Laboratory, and the procedures were as described previously (Trevisi et al., 2012; Batistel et al., 2016; Jacometo et al., 2016).

\section{Rumen Fluid Collection and Analyses}

Rumen fluid ( $\sim 50 \mathrm{~mL})$ was sampled 3 to $4 \mathrm{~h}$ after feeding on $-59,-29,5$, and 30 d relative to parturition from a subset of cows $(n=8$ multiparous cows/treatment) via esophageal tubing. After discarding the first $200 \mathrm{~mL}$ of fluid to minimize saliva contamination, approximately $50 \mathrm{~mL}$ of rumen fluid was collected. After collection, the rumen $\mathrm{pH}$ was immediately measured using a pH meter (Waterproof $\mathrm{pH}$ Test 30, Oakton Instruments). Two aliquots of $10 \mathrm{~mL}$ were saved in a bottle containing either $200 \mu \mathrm{L}$ of $50 \%$ sulfuric acid or $2 \mathrm{~mL}$ of $25 \%$ metaphosphoric acid and stored at $-20^{\circ} \mathrm{C}$ until analysis of ammonia $\mathrm{N}\left(\mathrm{NH}_{3}-\mathrm{N}\right)$ and VFA, respectively. Furthermore, $2 \mathrm{~mL}$ of rumen fluid samples were immediately frozen in liquid nitrogen followed by storage at $-80^{\circ} \mathrm{C}$ until DNA isolation, followed by relative abundance of bacteria species quantification via quantitative (q)PCR.

\section{Ammonia and VFA}

Rumen fluid samples preserved with sulfuric acid and $25 \%$ metaphosphoric acid were thawed and transferred into a 2-mL microcentrifuge tube and centrifuged at $30,000 \times g$ for $20 \mathrm{~min}$ at $4^{\circ} \mathrm{C}$ (model 5403, Eppendorf). The supernatant of rumen fluid sample with sulfuric acid was used to analyze ammonia $\mathrm{N}$ concentration, using the assay described by Chaney and Marbach (1962). Volatile fatty acid concentrations were measured in samples containing 25\% metaphosphoric acid using an automated gas chromatograph (model 689, HewlettPackard) equipped with a 0.25 -mm internal diameter $\times$ 15-m capillary column (Nukol 24106-U, Sulpeco Inc.), and the internal standard used was 2-ethylbutyrate.

\section{Ruminal Bacteria DNA Isolation and QPCR Amplification of $16 S$ rDNA Genes}

Ruminal bacteria DNA was isolated using the QIAmp Fast DNA Stool Mini Kit (Qiagen), with modifications to the protocol described by Henderson et al. (2013). Briefly, $1 \mathrm{~mL}$ of rumen fluid was centrifuged at 12,000 $\times g$ for $5 \mathrm{~min}$, and the supernatant was discarded. The pellet was resuspended in $1 \mathrm{~mL}$ of buffer EX from the Qiagen kit, vortexed, incubated in a heat block at $95^{\circ} \mathrm{C}$ for $5 \mathrm{~min}$, and centrifuged at 20,000 $\times g$ for $1 \mathrm{~min}$. Then, $600 \mu \mathrm{L}$ of supernatant was transferred to a new microcentrifuge tube that contained $25 \mu \mathrm{L}$ of Qiagen Proteinase K, followed by addition of $600 \mu \mathrm{L}$ of buffer AL from the Qiagen kit. The mixture was vortexed for $15 \mathrm{~s}$ and incubated at $70^{\circ} \mathrm{C}$ for $10 \mathrm{~min}$. After incubation, $600 \mu \mathrm{L}$ of $96 \%$ molecular ethanol was added and 
vortexed. The mixture was transferred into a QIAamp (Qiagen) mini spin column, and the subsequent steps were performed according to manufacturer's procedures. The DNA quantity and purity were measured using a Nanodrop spectrophotometer (ND 1000, Nanodrop Technologies Inc.), and the extracted DNA was standardized to $8 \mathrm{ng} / \mu \mathrm{L}$ for $\mathrm{qPCR}$.

The primer sets used in this study have been previously reported and validated (Supplemental Table S1, https://doi.org/10.6084/m9.figshare.14847711.v1). The $\mathrm{qPCR}$ analysis was performed using $10 \mu \mathrm{L}$ of qPCR mixture containing $4 \mu \mathrm{L}$ of sample DNA, $5 \mu \mathrm{L}$ of $1 \times$ SYBR Green master mix (Applied Biosystems), $0.4 \mu \mathrm{L}$ of $10 \mu M$ each for forward and reverse primers, and $0.2 \mu \mathrm{L}$ of nuclease-free water in a MicroAmp Optical 384-well reaction plate (Applied Biosystems). Each sample was run in triplicate, and the qPCR reactions were performed in a QuantStudio 6 Flex Real-Time PCR System (Applied Biosystems) using the same conditions described by Grazziotin et al. (2020). A geometrical mean of 2 universal bacteria primers was used to calculate the relative abundance of bacterial species (Abdelmegeid et al., 2018).

\section{Statistical Analysis}

The production data were analyzed throughout the study and separately for fresh (from 1 to $3 \mathrm{wk}$ postpartum) and high-producing (from 4 to 7 wk postpartum) periods (Supplemental Table S2, https://doi. $\mathrm{org} / 10.6084 / \mathrm{m}$ 9.figshare.14847711.v1). Data were analyzed as repeated measures with the MIXED procedure of SAS (SAS Institute Inc.) according to the following model:

$$
\begin{aligned}
\mathrm{Y}_{\mathrm{ijklm}}=\mu & +\mathrm{D}_{\mathrm{i}}+\mathrm{P}_{\mathrm{j}}+\mathrm{DP}_{\mathrm{ij}}+\mathrm{B}_{\mathrm{k}}+\mathrm{C}_{\mathrm{ijkl}}+\mathrm{T}_{\mathrm{m}} \\
& +\mathrm{DT}_{\mathrm{im}}+\mathrm{DPT}_{\mathrm{ijm}}+\mathrm{e}_{\mathrm{ijklm}},
\end{aligned}
$$

where $Y_{i j k l m}$ is the dependent, continuous variable; $\mu$ is the overall mean; $D_{i}$ is the fixed effect of the $i$ th treatment $(i=1$ and 2$) ; P_{j}$ is the fixed effect of the $j$ th parity $(j=1,2,3) ; D P_{i j}$ is the fixed effect of $i$ th treatment by the $j$ th parity of the experiment interaction; $B_{k}$ is the random effect of the $k$ th block $(k=1, \ldots, 20)$; $C_{i j k l}$ is the random effect of $l$ th cow nested within the $i$ th treatment, the $j$ th parity, and the $k$ th block $(l=1$, . $\left.\ldots, n_{i j k}\right) ; T_{m}$ is the fixed effect of the $m$ th time (day or week) of the experiment $(m=1, \ldots, n) ; D T_{i m}$ is the fixed effect of the $i$ th treatment by the $m$ th time of the experiment interaction; $D P T_{i j m}$ is the fixed effect of the $i$ th treatment by the $j$ th parity by the $m$ th time of the experiment interaction; and $e_{i j k l m}$ is the residual error. The sample size for blood biomarkers and rumen fluid data ( $\mathrm{n}=8 /$ treatment) taken in this study was based on prior studies on transition dairy cows evaluating ruminal microbial populations via PCR (Abdelmegeid et al., 2018; Elolimy et al., 2018). However, the authors acknowledge that reducing the sample size from 20 animals per treatment to 8 on blood biomarkers and rumen fluid data likely hampered the statistical power in this study. Repeated measure analyzed for equally spaced data (e.g., milk yield and BW) was modeled with autoregressive or heterogeneous autoregressive covariance structures and selected based on the least Bayesian information criterion value. Blood biomarkers and rumen fluid data, including $\mathrm{pH}, \mathrm{VFA}, \mathrm{NH}_{3}$, and relative abundance of microbial species, were analyzed at various time points that were not equally spaced; therefore, an exponential correlation covariance structure SP (POW) was used for repeated measures. Blood biomarkers and relative abundance of microbial species were log-scale transformed if needed, to comply with normal distribution of residuals. Blood biomarkers and rumen fluid data on -30 and $-59 \mathrm{~d}$ relative to calving, respectively, were used as covariates. The covariate of previous 305-d milk yield was maintained in the model for all variables for which it was significant $(P<0.05)$. Parity effect was removed from the model any time it was nonsignificant $(P>0.05)$. Health data were analyzed with the FREQ procedure of SAS and interpreted using Fisher's exact test probabilities. However, none of the health issues observed in this experiment were affected $(P \geq 0.11)$ by treatment effects (Table 1 ). Statistical significance was declared at $P \leq 0.05$ and tendencies at $P<0.10$.

\section{RESULTS}

\section{Peripartal DMI, BW, BCS, and EB}

Main effects and interactions for prepartal and postpartal BW, BCS, DMI, DMI as percent of BW, and EB are presented in Table 3. Neither prepartal nor postpartal BW, BCS, and DMI, DMI as percent of BW, and EB were affected $(P \geq 0.17)$ by dietary treatments.

\section{Milk Production and Composition}

Main effects and interactions for postpartal production variables and milk efficiency in terms of milk/DMI and ECM/DMI are presented in Table 4. The SCC was lower $(P<0.01)$ in $\mathrm{YC}$-fed cows than in control cows (Figure 1A). Although a diet effect for greater milk yield in $\mathrm{YC}$ cows than control did not reach statistical difference $(P=0.13$; Figure $1 \mathrm{~B})$, milk yield during the 
Table 3. Feed intake parameters, BW, BCS, and energy balance parameters for control cows and cows supplemented with a yeast culture fermentation product $(\mathrm{YC})$ from $-31 \pm 6 \mathrm{~d}$ relative to calving through $50 \mathrm{DIM}$

\begin{tabular}{|c|c|c|c|c|c|c|c|}
\hline Parameter & \multicolumn{2}{|c|}{ Treatment } & $\mathrm{SEM}^{1}$ & \multicolumn{4}{|c|}{$P$-value } \\
\hline BW. kg & 773 & 785 & 16.4 & 0.61 & $<0.01$ & 0.36 & 0.36 \\
\hline BCS & 3.12 & 3.19 & 0.08 & 0.56 & - & 0.12 & 0.81 \\
\hline DMI, kg/d & 12.2 & 12.7 & 0.61 & 0.59 & - & $<0.01$ & 0.21 \\
\hline \multicolumn{8}{|l|}{ Postpartum $^{4}$} \\
\hline $\mathrm{BW}, \mathrm{kg}$ & 688 & 688 & 13.75 & 0.99 & $<0.01$ & $<0.01$ & 0.92 \\
\hline BCS & 2.79 & 2.81 & 0.04 & 0.77 & - & $<0.01$ & 0.28 \\
\hline DMI, kg/day & 19.9 & 20.5 & 0.47 & 0.40 & $<0.01$ & $<0.01$ & 0.87 \\
\hline DMI, $\%$ of BW & 2.8 & 2.9 & 0.07 & 0.54 & — & $<0.01$ & 0.97 \\
\hline Energy balance, $\mathrm{Mcal} / \mathrm{d}$ & -4.61 & -6.46 & 1.25 & 0.17 & - & 0.22 & 0.99 \\
\hline
\end{tabular}

${ }^{1}$ Largest standard error of the mean.

${ }^{2}$ Interaction of treatment $\times$ time (week relative to parturition).

${ }^{3}$ Prepartum parameters were analyzed from $-30 \mathrm{~d}$ to calving.

${ }^{4}$ Postpartum parameters were analyzed from calving to 50 DIM.

high-producing period (4-7 wk postpartum) tended $(P$ $=0.10 ;$ Supplemental Table S2) to be greater in YC cows than in control cows. This was also confirmed by the trend $(P=0.07 ;$ Figure $1 \mathrm{C})$ for greater ECM in YC cows compared with control, where $\mathrm{YC}$ cows produced $3.2 \mathrm{~kg} / \mathrm{d}$ more ECM than control. Also, similar to milk yield, a trend $(P=0.11)$ was observed for a greater milk fat yield in $\mathrm{YC}$ cows compared with control. Milk efficiency in terms of milk/DMI was not affected $(P$ $=0.52$ ) by dietary treatments, and although milk efficiency in terms of ECM/DMI was approximately 0.10 greater in $\mathrm{YC}$ cows than control, this effect did not reach statistical significance $(P=0.18$; Figure $1 D)$.

\section{Rumen Fermentation}

Main effects and interactions for rumen fermentation characteristics are presented in Table 5 . We observed a treatment $(\mathbf{T r t}) \times$ time $(\mathbf{T})$ interaction in VFA concentrations of isovalerate $(P=0.05)$ and valerate $(P=$ 0.04 ; Figure 2). The Trt $\times \mathrm{T}$ in valerate was mainly associated with greater $(P=0.01)$ concentration in $\mathrm{YC}$ cows than in control at 5 DIM. In contrast to valerate, the Trt $\times \mathrm{T}$ in isovalerate was reflected in lower $(P<0.01)$ concentrations in $\mathrm{YC}$ cows than control at -29 DIM. The latter was reflected in lower $(P=0.02)$ isovalerate in $\mathrm{YC}$ cows compared with control.

Table 4. Milk production parameters and milk efficiency for dairy cows fed a basal diet (Control) or a basal diet supplemented with a yeast culture fermentation product (YC) from $-31 \pm 6$ d relative to calving through 50 DIM

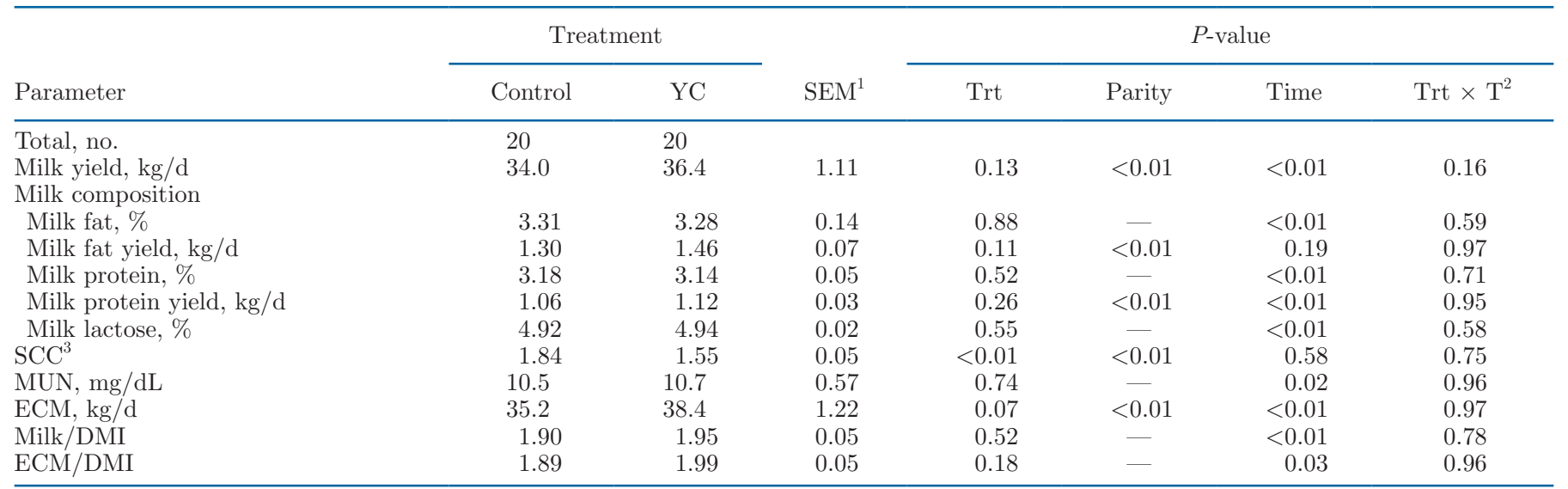

\footnotetext{
${ }^{1}$ Largest standard error of the mean.

${ }^{2}$ Interaction of treatment $\times$ time (week relative to parturition).

${ }^{3}$ Somatic cell counts were transformed to $\log _{10}$.
} 
$\longrightarrow$ Control $-\mathrm{O}-\mathrm{YC}$
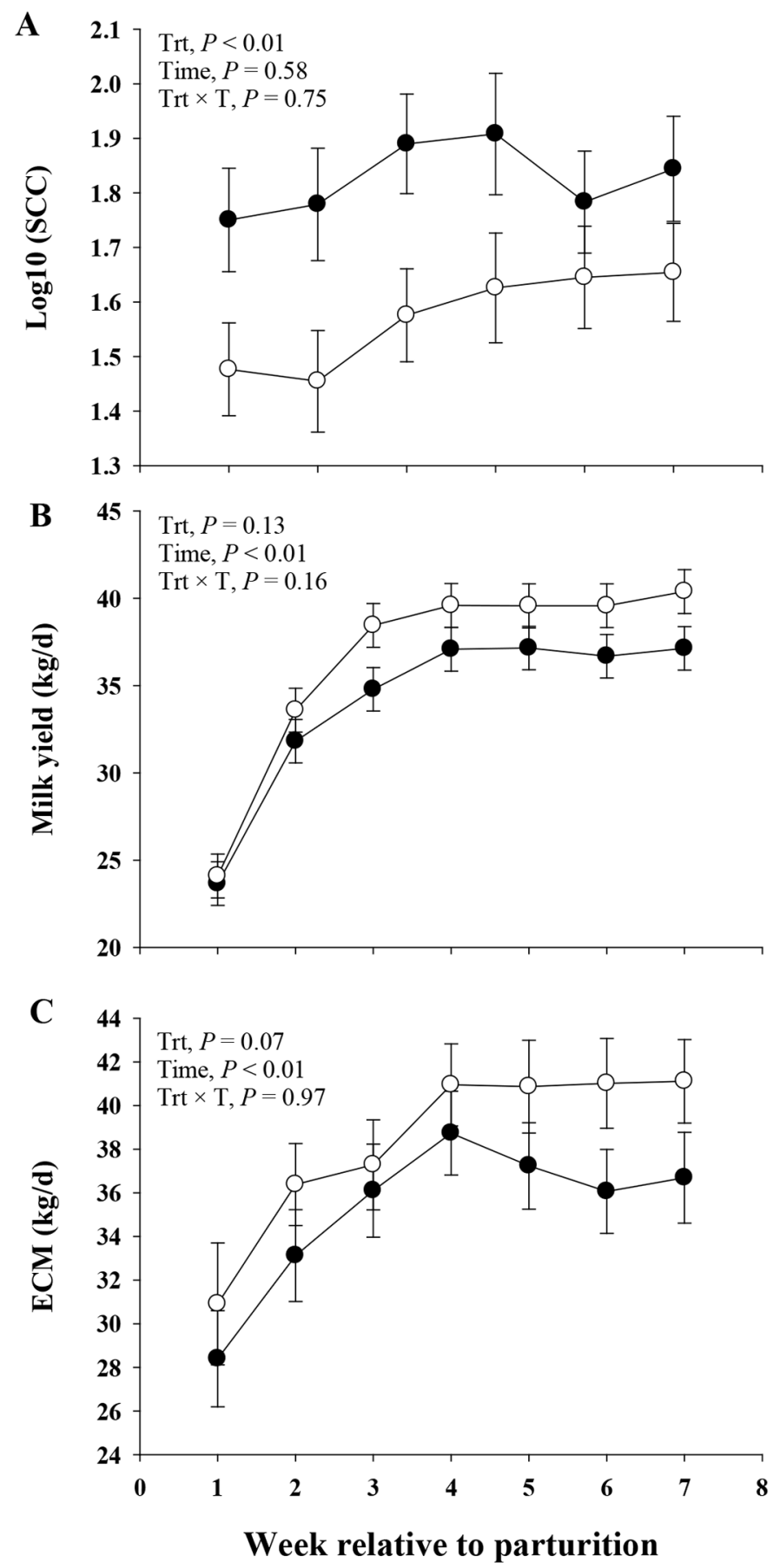

Figure 1. $\log _{10}$ SCC (A), milk yield (B), and ECM (C) in dairy cows $(\mathrm{n}=20$ /treatment) supplemented with a basal diet (Control) or basal diet plus yeast culture fermentation product (YC) from -31 $\pm 6 \mathrm{~d}$ relative to calving through 50 DIM. Trt $\times \mathrm{T}=$ interaction of treatment $\times$ time. Values are means, and SE are represented by vertical bars.

\section{Abundance of Ruminal Bacteria}

Main effects and interactions for the relative abundance of microbial species in rumen fluid are presented in Table 6 . We detected a Trt $\times \mathrm{T}$ interaction $(P \leq$ $0.05)$ on the relative abundance of Prevotella albensis, Prevotella bryantii, Prevotella ruminicola, and Succinivibrio dextrinosolvens (Figure 3 ). The Trt $\times$ T observed in $P$. albensis was associated with a greater $(P=0.03)$ abundance of this bacterium in $\mathrm{YC}$ cows than control at 30 DIM. The Trt $\times \mathrm{T}$ in $P$. ruminicola resulted in lower $(P=0.01)$ abundance of this bacterium in $\mathrm{YC}$ cows in comparison to control at 5 DIM. The Trt $\times$ $\mathrm{T}$ in Succinivibrio dextrinosolvens $(P=0.05)$ and $P$. bryantii $(P=0.05)$ resulted in a similar pattern, where lower abundance of these bacteria was observed in $\mathrm{YC}$ cows than control at -29 DIM. We found a greater relative abundance of Megasphaera elsdenii $(P=0.05)$ and Succinimonas amylolytica $(P=0.03)$ in $\mathrm{YC}$ cows than in control (Table 6). In contrast with M. elsdenii and Succinimonas amylolytica, Prevotella brevis abundance was lower $(P<0.01)$ in $\mathrm{YC}$ cows compared with control. In addition, we discovered a trend for greater abundance of Fibrobacter succinogenes $(P=0.09)$ in $\mathrm{YC}$ cows than control.

\section{Blood Biomarkers}

Main effects and interactions for blood biomarkers of muscle body mass, metabolism, and oxidative stress are presented in Table 7 . We observed a Trt $\times \mathrm{T}$ interaction $(P=0.02)$ in NEFA (Figure 4$)$. The Trt $\times \mathrm{T}$ in NEFA resulted in lower NEFA in YC cows than control at $-15(P=0.05), 14(P=0.05)$, and $30 \mathrm{~d}(P=0.02)$ relative to parturition, whereas a tendency $(P=0.12)$ for greater NEFA was observed in YC cows than in control at 7 DIM (Figure 4). These effects at $-15,14$, and 30 DIM can be attributed to a trend $(P=0.10)$ for overall lower NEFA in YC cows than in control.

\section{DISCUSSION}

\section{Effects on DMI, BW, and BCS}

Peripartal dairy cows commonly experience a decline in DMI around parturition (Drackley, 1999). This decline in DMI commonly results in low energy intake, which has been associated with BCS and hormonal changes around parturition (Ingvartsen and Andersen, 2000). As a result of this decrease in energy intake, dairy cows enter a NEB state that is exacerbated by the substantial increase in energy demands to sustain milk production after calving. Dairy cows respond to NEB by mobilizing lipids from adipose tissue in the form of 
Table 5. Ruminal pH, ammonia, and rumen fermentation parameters for dairy cows fed a basal diet (Control) or a basal diet supplemented with a yeast culture fermentation product $(\mathrm{YC})$ from $-31 \pm 6 \mathrm{~d}$ relative to calving through $50 \mathrm{DIM}$

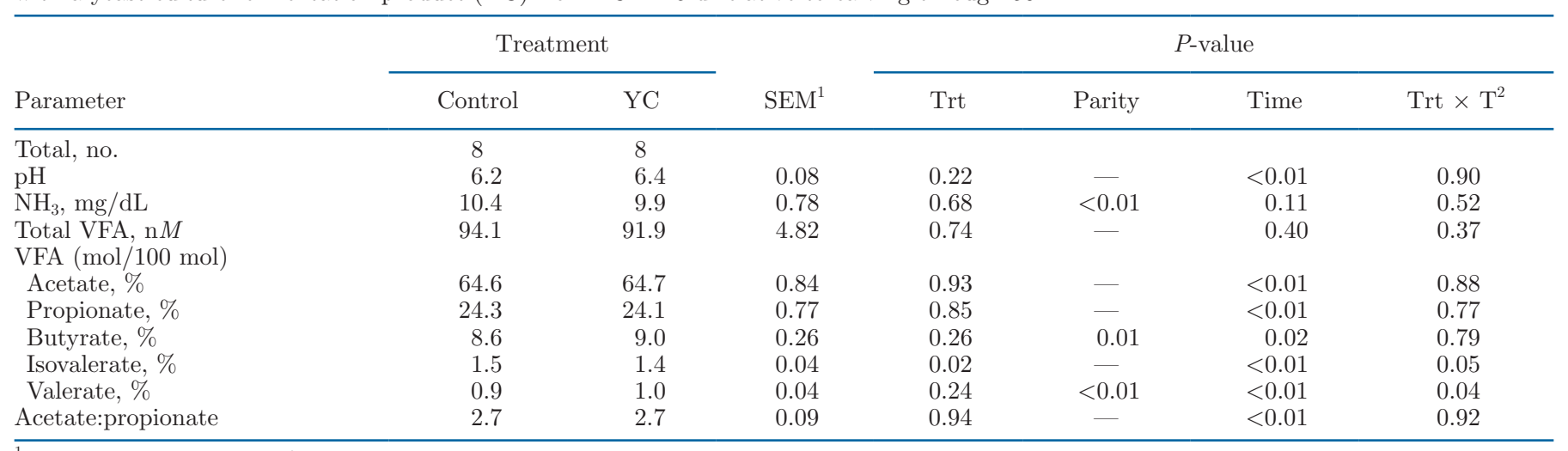

${ }^{1}$ Largest standard error of the mean.

${ }^{2}$ Interaction of treatment $\times$ time (day relative to parturition).

NEFA, to cope with energy demands in early lactation (Contreras and Sordillo, 2011). For these reasons, it is typical to observe a decrease in BCS and BW in dairy cows during early lactation.

Yeast culture has been supplemented to dairy cows with the aim of improving performance and health (Poppy et al., 2012). The outcomes of yeast culture supplementation during the transition period have been inconsistent, especially in DMI. For instance, Dann et al. (2000) observed improvements in DMI during the first 42 DIM in peripartal Jersey dairy cows fed $60 \mathrm{~g} / \mathrm{d}$ of a yeast culture product. In contrast, neither Olagaray et al. (2019) nor Shi et al. (2019a) observed an overall improvement in DMI during the transition period when feeding yeast culture products at approximately 17 and $19 \mathrm{~g} / \mathrm{d}$, respectively. Similarly, in the current study, yeast culture supplementation did not affect peripartal DMI, and by extension, no effect on BW or BCS was observed around parturition.

\section{Milk Production and Milk Components}

Lack of consistency has been observed in the milk yield response to yeast supplementation in dairy cows. This is predicated on the multiple forms (e.g., active and dead), packing, and metabolites that can be incorporated in commercial yeast supplements. For instance, feeding yeast culture products has been observed to increase milk yield between 3.3 and $5.2 \mathrm{~kg} / \mathrm{d}$ in transition and mid-lactation dairy cows (Zaworski et al., 2014; Dias et al., 2018). Robinson and Erasmus (2009) reviewed several yeast culture studies in dairy cows and reported that overall yeast supplementation has a positive effect on milk yield $(\sim 0.9 \mathrm{~kg} / \mathrm{d})$. In contrast, studies reported no effect on milk production in transition dairy cows (Yuan et al., 2015a; Olagaray et al.,
2019; Stefenoni et al., 2020). A positive effect on milk production was observed in YC cows, with an increase of $2.5 \mathrm{~kg} / \mathrm{d}$, which was within the range of milk yield improvement observed in previous studies feeding yeast supplements.

Yeast culture supplementation has been observed to improve milk fat yield in early and mid-lactation dairy cows (Dias et al., 2018; Perdomo et al., 2020). Olagaray et al. (2019) observed a $0.13-\mathrm{kg} / \mathrm{d}$ increase in milk fat yield at 4 and 5 wk postpartum, feeding $19 \mathrm{~g} / \mathrm{d}$ of yeast culture during the peripartal period, which was similar to the $0.16-\mathrm{kg} / \mathrm{d}$ increase in milk fat yield observed in YC cows compared with control. Diets containing relatively high levels of unsaturated fats and starch have been associated with milk fat depression in dairy cows because of increased flow of trans fatty acids from ruminal fermentation (Bradford and Allen, 2004). In this context, Longuski et al. (2009) reported that lactating dairy cows supplemented with yeast culture had a higher degree of resistance to milk fat depression during a short-term dietary challenge with fermentable starch. This can be in part ascribed to yeast maintaining a favorable rumen environment for cellulolytic bacteria, which is the primary source of ruminal acetate. Therefore, yeast supplementation may indirectly promote a stable supply of acetate for milk fat synthesis by maintaining a favorable population of cellulolytic bacteria (Ghazanfar et al., 2017).

The benefits of yeast culture supplementation on milk performance parameters in the present study were reflected in ECM. These results agree with those of Dias et al. (2018), in which yeast culture caused an increase in ECM. According to Dias et al. (2018), supplementation of yeast culture from $S$. cerevisiae could increase ECM in lactating cows fed diets varying in starch content. In contrast, others did not observe positive effects 
in ECM in transition dairy cows supplemented with yeast derived from S. cerevisiae (Yuan et al., 2015a; Stefenoni et al., 2020). The fermentable metabolites present in $\mathrm{YC}$ may have improved nutrient utilization by ruminal bacteria and consequently allowed a higher milk yield performance in YC fed cows.

Improvements in udder health, in terms of SCC, have been observed when feeding yeast culture products to
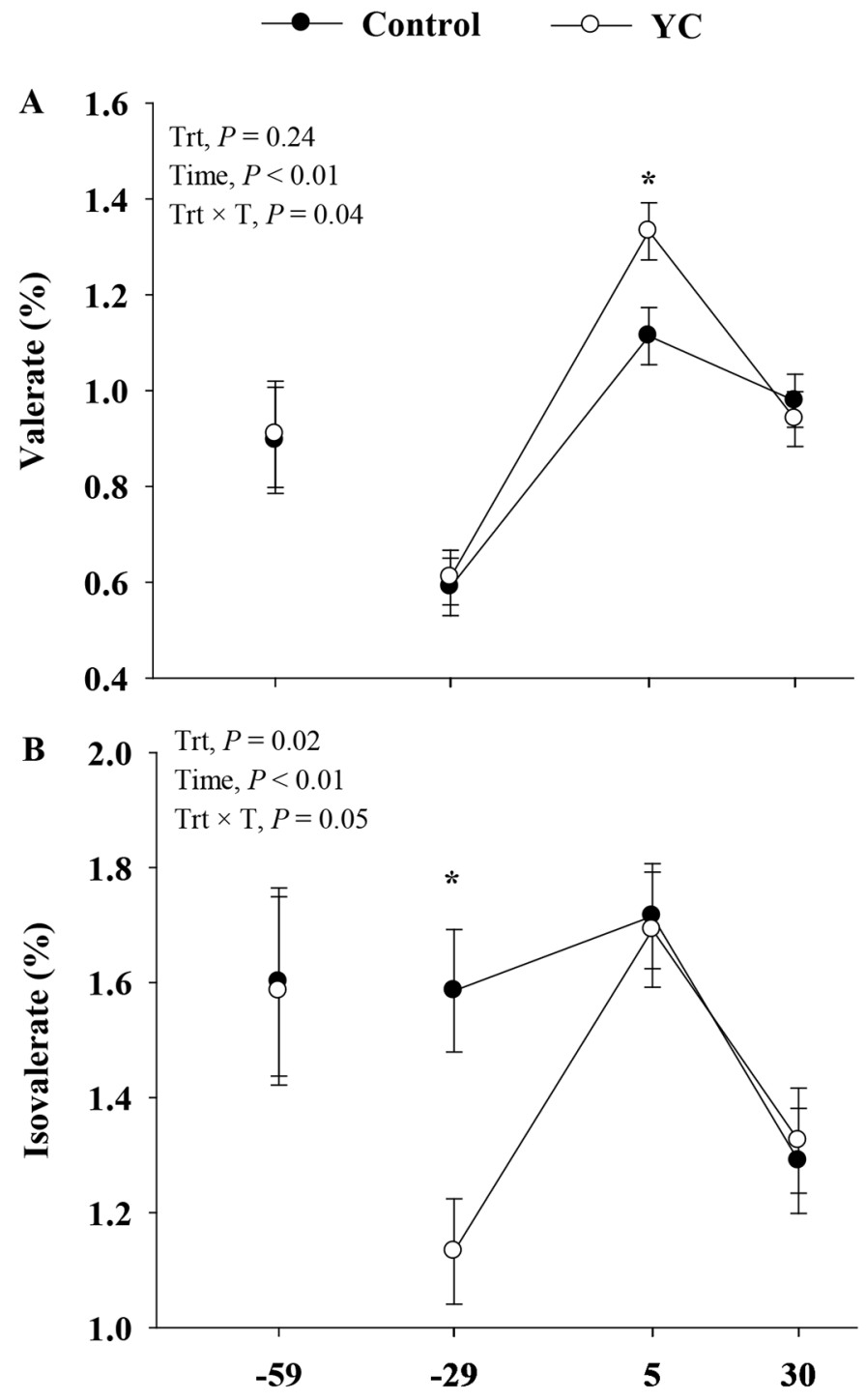

Day relative to parturition

Figure 2. Ruminal valerate (A) and isovalerate (B) in dairy cows $(\mathrm{n}=8 /$ treatment $)$ supplemented with a basal diet (Control) or basal diet plus yeast culture fermentation product (YC) from $-31 \pm 6 \mathrm{~d}$ relative to calving through 50 DIM. Mean separations between diets at a given time point were evaluated when a treatment $\times$ time (Trt $\times \mathrm{T})$ interaction $(P \leq 0.05)$ was observed, and differences $(*)$ were declared at $P \leq 0.05$. Values are means, and SE are represented by vertical bars. dairy cows. For instance, Nocek et al. (2011) tested a yeast culture product alone or in combination with an enzymatically hydrolyzed yeast fed to dairy cows from calving to $14 \mathrm{wk}$ postpartum. This combination resulted in lower SCC through the first $14 \mathrm{wk}$ of lactation. Zaworski et al. (2014) reported positive effects on SCC during the first 4 wk postpartum when supplementing different dosages of $S$. cerevisiae fermentation product. Those effects were attributed to a potential activation of the animal's immune system at the gut level by antigenic exposure in the form of $\beta$-glucans and mannan-oligosaccharides presented in some yeast products. Besides a systemic activation of the immune system as described by Nocek et al. (2011), the action of $\beta$-glucans has been tested at the local level during a mastitis induction (Persson Waller et al., 2003). Persson Waller et al. (2003) evaluated the effects of an intramammary infusion of $\beta$-1,3-glucan in dairy cows under a chronic subclinical mastitis model induced by Staphylococcus aureus. They did not observe any beneficial effects of $\beta-1,3$-glucan in reducing subclinical mastitis. However, a tendency to increase milk lymphocytes after $\beta$-1,3-glucan infusion was observed, suggesting that, to some extent, $\beta$-1,3-glucan may stimulate a better local inflammatory response by increasing immune cell recruitment.

\section{Rumen Fermentation Parameters}

Dietary carbohydrates are fermented by ruminal bacteria, fungi, and protozoa into end products, including VFA (e.g., acetate, propionate, and butyrate) that make up for nearly $50 \%$ of the energy requirements for ruminants (Puniya et al., 2015). Desnoyers et al. (2009) reported in a meta-analysis that yeast supplementation increased total VFA concentration in domesticated ruminant species. Zhu et al. (2017) reported a positive effect on total VFA when mid-lactation dairy cows were supplemented with $S$. cerevisiae fermentation product, which was associated with a stimulatory effect on rumen microbial populations, including cellulolytic bacteria. In transition dairy cows, less evidence for an improvement in total VFA as a result of yeast culture supplementation has been reported (Robinson and Garrett, 1999; Dias et al., 2018; Shi et al., 2019b). In the same way, total VFA production was not affected by yeast culture supplementation in the current study.

The normal transition of dairy cows from late pregnancy into lactation is predicated on the cow's ability to adapt to a postpartal lactation diet, which leads to increased ruminal butyrate and valerate, while other VFA such as isobutyrate and isovalerate remained unchanged (Minuti et al., 2015). The primary ruminal VFA (i.e., acetate, propionate, and butyrate) seem to 
be less responsive to yeast supplementation in transition dairy cows (Robinson and Garrett, 1999; Kumprechtová et al., 2019). Similar to transition dairy cows, yeast culture and live yeast culture supplementation in mid-lactation dairy cows did not elicit an effect on acetate, propionate, and butyrate (Dias et al., 2018; Meller et al., 2019). In agreement with those data, our results showed that supplementing YC during the transition period did not influence the concentration of the main VFA.

Ruminal isoacids, comprising isobutyrate, 2-methylbutyrate, isovalerate, and valerate, have been found to respond to yeast culture supplementation (Andries et al., 1987). For instance, in an experiment testing incremental levels of concentrate plus yeast culture supplementation $(1 \mathrm{~g} / \mathrm{kg}$ of TMR as fed), yeast culture was shown to increase the concentrations of isobutyrate and isovalerate regardless of concentrate level in the diet in cannulated Holstein dairy heifers (Lascano and Heinrichs, 2009). Lactating dairy cows fed a high dose of inactivated yeast had an increased molar proportion of valerate compared with control cows (Jiang et al., 2017), which is consistent with the increase in valerate in YC cows at 5 DIM. An alternative explanation for the increase in valerate could be associated with the greater M. elsdenii in YC cows, which was more evident postpartum (Supplemental Figure S1, https://doi.org/10.6084/m9.figshare.14847711.v1). The latter is based on the fact that $M$. elsdenii can ferment L-lactate into propionate and subsequently valerate (Weimer and Moen, 2013). In addition, live yeast supplementation increased the concentration of isovalerate in early-lactation dairy cows under heat stress conditions (Garcia Diaz et al., 2018; Perdomo et al., 2020). Similar findings for isovalerate were observed in the present study, where this isoacid increased in YC cows in early lactation. However, others have observed no changes in valerate and isovalerate concentrations in response to supplementation of active dry $S$. cerevisiae in cannulated lactating dairy cows (AlZahal et al., 2014). Interestingly, Harrison et al. (1988) and coworkers observed a decrease in the molar proportion of isovalerate while valerate increased in lactating cows fed a yeast culture supplement. This effect was attributed to lower ruminal $\mathrm{pH}$ in yeast culture-supplemented cows. The positive effects of yeast in ruminal valerate concentrations can be associated with changes in metabolic activities of ruminal bacteria, including amylolytic, cellulolytic, and lactate-utilizing populations. For instance, ruminal degradation of proteins by amylolytic bacteria commonly leads to production of isoacids (Dawson et al., 1990), whereas the fermentation pathway of lactate by ruminal bacteria may lead to the production of valerate (Weimer and Moen, 2013). These isoacids are required for most cellulolytic bacteria to degrade fiber, underscoring the essential role of isoacids in fiber digestibility (Liu et al., 2009).

Table 6. Relative abundance (\%) of target bacterial species in mixed ruminal fluid for dairy cows fed a basal diet (Control) or a basal diet supplemented with a yeast culture fermentation product $(\mathrm{YC})$ from $-31 \pm 6$ d relative to calving through 50 DIM

\begin{tabular}{|c|c|c|c|c|c|c|}
\hline \multirow[b]{2}{*}{ Species $^{1}$} & \multicolumn{2}{|c|}{ Treatment } & \multirow[b]{2}{*}{$\mathrm{SEM}^{2}$} & \multicolumn{3}{|c|}{$P$-value } \\
\hline & Control & $\mathrm{YC}$ & & Trt & Time & $\operatorname{Trt} \times \mathrm{T}^{3}$ \\
\hline Total, no. & 8 & 8 & & & & \\
\hline Anaerovibrio lipolytica & $1.36 \times 10^{-3}$ & $1.83 \times 10^{-3}$ & 0.19 & 0.12 & 0.26 & 0.39 \\
\hline Butyrivibrio fibrisolvens & $8.53 \times 10^{-4}$ & $9.92 \times 10^{-4}$ & 0.15 & 0.32 & 0.27 & 0.87 \\
\hline Butyrivibrio proteoclasticus & $1.28 \times 10^{-1}$ & $1.28 \times 10^{-1}$ & 0.15 & 0.98 & 0.37 & 0.48 \\
\hline Eubacterium ruminantium & $8.51 \times 10^{-3}$ & $9.04 \times 10^{-3}$ & 0.22 & 0.78 & 0.25 & 0.39 \\
\hline Fibrobacter succinogenes & $5.52 \times 10^{-2}$ & $7.27 \times 10^{-2}$ & 0.15 & 0.09 & 0.04 & 0.47 \\
\hline Megasphaera elsdenii & $3.65 \times 10^{-4}$ & $5.53 \times 10^{-4}$ & 0.22 & 0.05 & $<0.01$ & 0.49 \\
\hline Prevotella albensis & $2.61 \times 10^{-3}$ & $4.58 \times 10^{-3}$ & 0.65 & 0.40 & $<0.01$ & 0.01 \\
\hline Prevotella brevis & $8.74 \times 10^{-2}$ & $7.12 \times 10^{-2}$ & 0.04 & $<0.01$ & 0.04 & 0.70 \\
\hline Prevotella bryantii & $2.96 \times 10^{-2}$ & $2.30 \times 10^{-2}$ & 0.58 & 0.66 & $<0.01$ & 0.05 \\
\hline Prevotella ruminicola & $8.20 \times 10^{-1}$ & $7.43 \times 10^{-1}$ & 0.11 & 0.36 & 0.99 & 0.02 \\
\hline Ruminococcus albus & $2.59 \times 10^{-3}$ & $2.59 \times 10^{-3}$ & 0.23 & 0.99 & 0.19 & 0.98 \\
\hline Ruminococcus flavefaciens & $6.38 \times 10^{-4}$ & $6.51 \times 10^{-4}$ & 0.38 & 0.96 & 0.08 & 0.26 \\
\hline Ruminobacter amylophilus & $1.29 \times 10^{-3}$ & $2.63 \times 10^{-3}$ & 0.82 & 0.39 & 0.42 & 0.45 \\
\hline Selenomonas ruminantium & $2.32 \times 10^{-1}$ & $2.39 \times 10^{-1}$ & 0.10 & 0.73 & 0.04 & 0.11 \\
\hline Succinimonas amylolytica & $1.85 \times 10^{-3}$ & $4.63 \times 10^{-3}$ & 0.39 & 0.03 & 0.13 & 0.12 \\
\hline Succinivibrio dextrinosolvens & $5.22 \times 10^{-3}$ & $6.78 \times 10^{-3}$ & 0.53 & 0.63 & 0.66 & 0.05 \\
\hline Streptococcus bovis & $9.62 \times 10^{-4}$ & $9.54 \times 10^{-4}$ & 0.27 & 0.97 & 0.02 & 0.42 \\
\hline Treponema bryantii & $4.37 \times 10^{-3}$ & $5.62 \times 10^{-3}$ & 0.33 & 0.46 & 0.18 & 0.76 \\
\hline
\end{tabular}

${ }^{1}$ Data were log-transformed before statistics. The SEM associated with log-transformed data are in log scale.

${ }^{2}$ Largest standard error of the mean.

${ }^{3}$ Interaction of treatment $\times$ time (day relative to parturition). 

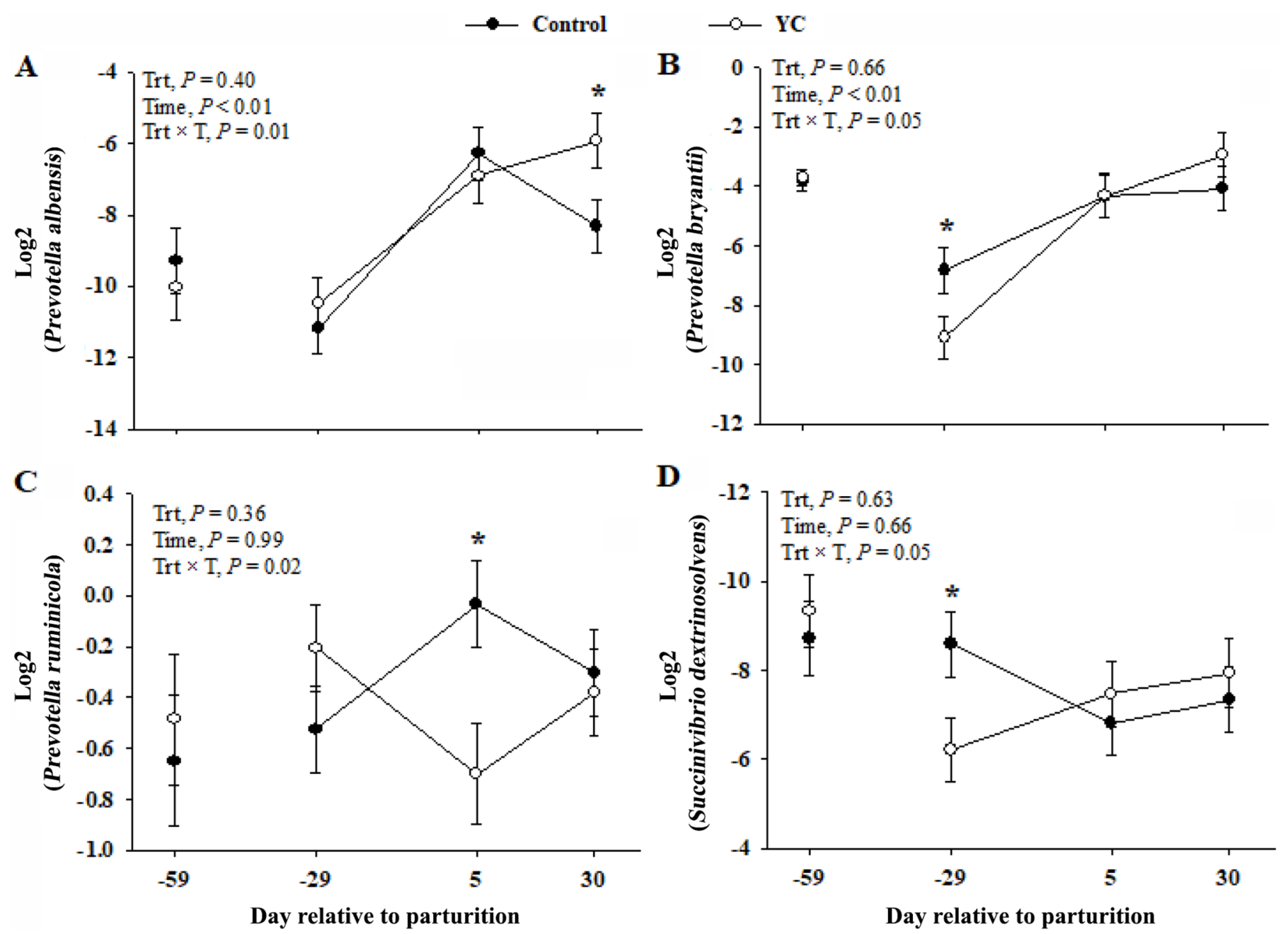

Figure 3. Relative abundance (\%) of Prevotella albensis (A), Prevotella bryantii (B), Prevotella ruminicola (C), and Succinivibrio dextrinosolvens $(\mathrm{D})$ in microbial species evaluated in rumen fluid in dairy cows $(\mathrm{n}=8$ /treatment) supplemented with a basal diet (Control) or basal diet plus yeast culture fermentation product (YC) from $-31 \pm 6 \mathrm{~d}$ relative to calving through 50 DIM. Mean separations between diets at a given time point were evaluated when a treatment $\times$ time $($ Trt $\times \mathrm{T})$ interaction $(P \leq 0.05)$ was observed, and differences $(*)$ were declared at $P \leq$ 0.05. Values are means, and SE are represented by vertical bars.

\section{Yeast Culture and Ruminal Bacteria Species}

The rumen environment is malleable, to some extent, and positive modifications can affect bacteria populations and, by extension, their fermentation products, leading to improved performance and nutrient utilization in ruminants (Ghazanfar et al., 2017). Different mechanisms have been proposed to explain the action of yeast in the rumen. For instance, yeast culture products provide mannooligosaccharides and glucans present in the yeast cell wall that can be highly degradable in the rumen, as well as fermentable metabolites, minerals, and enzymes that can change the profile and physiology of ruminal bacteria, stimulating the growth of cellulolytic, amylolytic, and proteolytic bacteria
(Chaucheyras-Durand et al., 2008; Ghazanfar et al., 2017; Jiao et al., 2019).

The effect of yeast culture products on ruminal bacteria abundance has been evaluated in lactating dairy cows (AlZahal et al., 2014; Zhu et al., 2017; Jiao et al., 2019). However, less is known about the effect of yeast culture on ruminal bacteria abundance in transition dairy cows. We found positive effects on bacterial populations in YC cows in the current study, mainly by increasing lactate- and fiber-digesting bacteria. Similar to the current study findings, early-lactating dairy cows supplemented with live yeast presented a greater abundance of lactate-utilizing bacteria (Megasphaera) and fiber-digesting bacteria (Fibrobacter; Pinloche et al., 2013). 
Table 7. Blood biomarkers related to muscle body mass, metabolism, and oxidative stress for dairy cows fed a basal diet (Control) or a basal diet supplemented with a yeast culture fermentation product (YC) from $-31 \pm 6$ d relative to calving through 50 DIM

\begin{tabular}{|c|c|c|c|c|c|c|}
\hline \multirow[b]{2}{*}{ Parameter } & \multicolumn{2}{|c|}{ Treatment } & \multirow[b]{2}{*}{$\mathrm{SEM}^{1}$} & \multicolumn{3}{|c|}{$P$-value } \\
\hline & Control & $\mathrm{YC}$ & & Trt & Time & $\operatorname{Trt} \times \mathrm{T}^{2}$ \\
\hline $\begin{array}{l}\text { Muscle body mass } \\
\text { Creatinine, } \mu \mathrm{mol} / \mathrm{L}\end{array}$ & \multicolumn{6}{|c|}{ Muscle body mass } \\
\hline Urea, $\mathrm{mmol} / \mathrm{L}$ & $\begin{array}{r}88.1 \\
4.60\end{array}$ & 4.58 & $\begin{array}{l}1.04 \\
0.14\end{array}$ & $\begin{array}{l}0.30 \\
0.92\end{array}$ & $\begin{array}{r}<0.01 \\
0.19\end{array}$ & $\begin{array}{l}0.56 \\
0.39\end{array}$ \\
\hline \multicolumn{7}{|l|}{ Metabolism } \\
\hline $\mathrm{BHB},{ }^{3} \mathrm{mmol} / \mathrm{L}$ & 0.43 & 0.42 & 0.06 & 0.83 & $<0.01$ & 0.13 \\
\hline \multicolumn{7}{|l|}{ Oxidative stress ${ }^{4}$} \\
\hline $\mathrm{ROM}, \mathrm{mg} \mathrm{H}_{2} \mathrm{O}_{2} / 100 \mathrm{~mL}$ & 14.0 & 15.0 & 0.52 & 0.19 & 0.03 & 0.40 \\
\hline FRAP,$\mu \mathrm{mol} / \mathrm{L}^{3}$ & 142.0 & 136.3 & 0.04 & 0.28 & $<0.01$ & 0.48 \\
\hline
\end{tabular}

${ }^{1}$ Largest standard error of the mean.

${ }^{2}$ Interaction of treatment $\times$ time (day relative to parturition).

${ }^{3}$ Data were log-transformed before statistics. The SEM associated with log-transformed data are in log scale.

${ }^{4} \mathrm{ROM}=$ reactive oxygen metabolites; FRAP $=$ ferric reducing antioxidant power.

Minuti et al. (2015) observed a decrease in postpartal F. succinogenes abundance in transition dairy cows, primarily driven by high grain content in the lactation diet. A trend $(P=0.09)$ for greater $F$. succinogenes

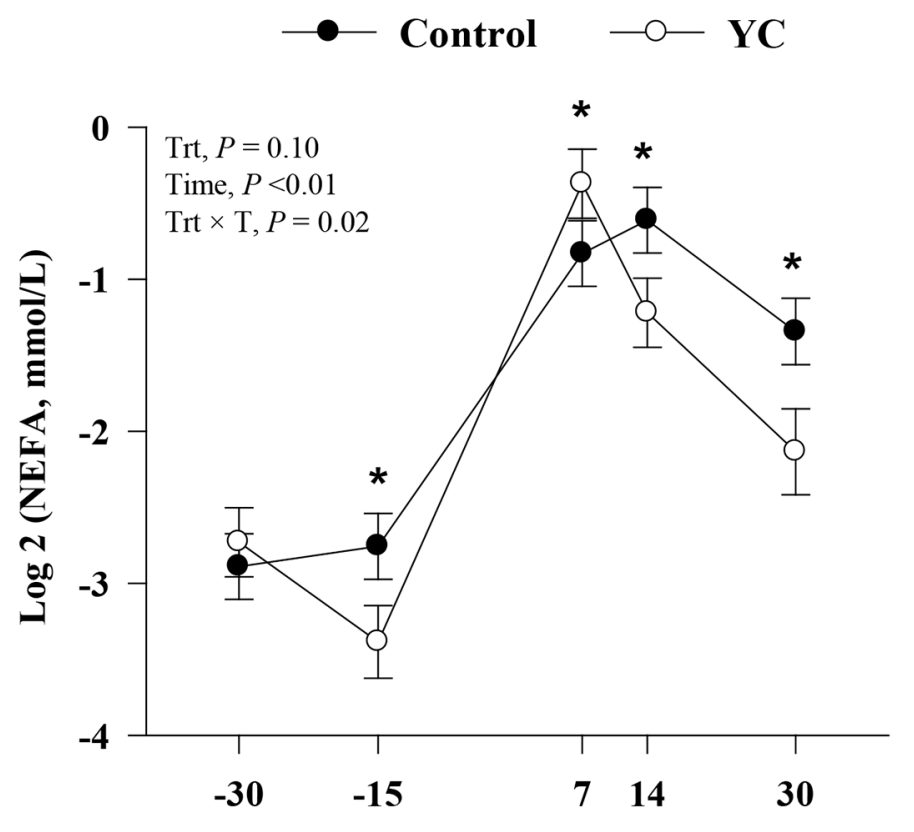

Day relative to parturition

Figure 4. Blood nonesterified fatty acids (NEFA) in cows $(\mathrm{n}=8 /$ treatment) supplemented with a basal diet (Control) or basal diet plus yeast culture fermentation product $(\mathrm{YC})$ from $-31 \pm 6 \mathrm{~d}$ relative to calving through 50 DIM. Mean separations between diets at a given time point were evaluated when a treatment $\times$ time $($ Trt $\times \mathrm{T})$ interaction $(P \leq 0.05)$ was observed, and differences $(*)$ were declared at $P \leq 0.05$. Values are means, and $\mathrm{SE}$ are represented by vertical bars. abundance in $\mathrm{YC}$ cows compared with control was observed, and such effect was more evident at 30 DIM (Supplemental Figure S1B). A similar response was reported by Zhu et al. (2017), where F. succinogenes increased linearly in lactating dairy cows receiving incremental amounts $(0,60,120$, and $160 \mathrm{~g} / \mathrm{d})$ of $S$. cerevisiae fermentable products. In contrast, other studies in vitro and in vivo did not observe a yeast effect in $F$. succinogenes abundance (Mullins et al., 2013; Jiao et al., 2019). The improvements in abundance and activity of fiber digesting bacteria via yeast culture supplementation could result in greater fiber digestibility and stable ruminal $\mathrm{pH}$. These associations cannot be confirmed in the current study because fiber digestibility was not evaluated, and perhaps additional factors, such as sample size or number of time points when rumen $\mathrm{pH}$ was assessed during the transition period, did not allow determination of potential alterations in rumen $\mathrm{pH}$ as a result of yeast culture supplementation.

Lactate-associated bacteria such as $M$. elsdenii can utilize lactate as an energy source and, consequently, slower growth rates of these bacteria are observed in low-carbohydrate diets (Russell, 2002; Puniya et al., 2015). Increased abundance of M. elsdenii has been observed in transition dairy cows after calving, attributed to greater DMI and starch digestibility (Minuti et al., 2015). Similarly, live yeast supplementation has been reported to increase ruminal abundance of $M$. elsdenii (Ogunade et al., 2019). In the present study, lactate was not evaluated, but $M$. elsdenii increased regardless of treatments after calving, consistent with greater starch content in lactation diets. Additionally, the increase in the abundance of these bacteria in YC cows was more pronounced at 30 DIM (Supplemental Figure S1A and 
S1C), suggesting that these bacteria were affected by yeast supplementation beyond the expected increase because of greater starch content in the lactation diet. Yeast culture products seem to contain growth factors that stimulate the development of ruminal bacteria, specifically lactate utilizers (Callaway and Martin, 1997; Chaucheyras-Durand et al., 2008). Shabat et al. (2016) found M. elsdenii to be highly correlated with feed efficiency and indicate that this type of bacterium may reroute ruminal lactate to propionate synthesis, consequently helping to control rumen $\mathrm{pH}$. The reasons for the increase in ruminal abundance of $M$. elsdenii more evidently occurring after calving in YC cows remains unknown, but perhaps we could speculate that this was an interaction between diet (i.e., close-up and lactation) and yeast culture supplementation.

Abdelmegeid et al. (2018) observed a greater abundance of Succinivibrio dextrinosolvens prepartum compared with postpartum, and Succinimonas amylolytica tended to follow the same pattern. In contrast, we observed no change over time in both bacteria, regardless of treatment (Figure 3E and 3F). These data conflict with these bacteria's known starch-degrading function (Russell, 2002), which implies that such bacteria abundance should increase postpartum.

We found a prepartal increase of Succinimonas amylolytica with a contrasting decrease of Succinivibrio dextrinosolvens in YC cows compared with control. These effects on Succinimonas amylolytica and Succinivibrio dextrinosolvens took place within $24 \mathrm{~h}$ after initial supplementation with YC ( -30 DIM), which renders these effects short-term and potentially transient as the rumen adapted to YC supplementation. Alternatively, these effects on Succinimonas amylolytica and Succinivibrio dextrinosolvens abundance may be attributable to the change from a far-off to a close-up diet around $-30 \mathrm{~d}$ before expected calving.

Prevotella species can use a variety of substrates, such as starch, hemicellulose, pectin, $\beta$-glucans, and proteins, to produce acetate, propionate, succinate, and formate (Russell, 2002). The presence of Prevotella spp. in the rumen across a variety of diets indicates the substantial metabolic diversity of this genus (Zeineldin et al., 2018). According to Stevenson and Weimer (2007), bacteria population of the genus Prevotella are the most dominant bacteria in the rumen, but only a small percentage is composed of P. bryantii, P. brevis, and $P$. ruminicola in lactating dairy cows fed a normal TMR diet. This was later confirmed by Lima et al. (2015), showing that Prevotella is the most abundant bacterium in transition cows.

In the current study, different responses to $\mathrm{YC}$ supplementation were observed for $P$. albensis, $P$. bryantii, $P$. brevis, and $P$. ruminicola, confirming the metabolic diversity of this genus in the rumen. The current study's findings showed a greater abundance of $P$. albensis in $\mathrm{YC}$ cows at 30 DIM (Figure 3A), suggesting that $\mathrm{YC}$ supplementation coupled with an eventual adaptation to the lactation diet promoted an increase of this bacterium. Prevotella bryantii was lower in cows supplemented with YC at -29 DIM, which seems to be similar to results for Succinimonas amylolytica and Succinivibrio dextrinosolvens, where such an effect might be transient rather than a 24-h response to YC supplementation. Overall, P. bryantii increased postpartum regardless of dietary treatments (Figure 3B), which was a similar pattern to that observed by Minuti et al. (2015). Subacute ruminal acidosis induced via grain or alfalfa pellets caused a differential response among the Prevotella genus, specifically, $P$. ruminicola and $P$. albensis, which further underscores the metabolic diversity of this genus (Khafipour et al., 2009). Our results suggest that Prevotella spp. behave differently in response to $\mathrm{YC}$ supplementation, which is in line with previous differential response across Prevotella spp. An alternative explanation for the different abundance among Prevotella spp. could be related to their ability to use signaling molecules such as N-acyl homoserine lactones to communicate between bacteria in an orchestrated effect to coordinate bacterial population density, also known as quorum sensing (Won et al., 2020). Interactions through quorum sensing have been evaluated between yeast and bacteria (Proust et al., 2020). However, the specific mechanisms and interactions between YC products and ruminal bacteria such as Prevotella spp. remains unclear.

Taken together, yeast culture supplementation promoted changes in rumen bacteria species across cellulolytic, amylolytic, and lactate-utilizing species. These effects seem to have promoted beneficial rumen fermentation, at least in terms of valerate, which might have promoted better fiber digestion. The researchers speculate that the presence of lactate-utilizing bacteria may be helpful during the periods when the diet changes abruptly, such as the transition period. The abrupt change from a high-fiber diet prepartum to a lactation diet postpartum, containing large amounts of fermentable carbohydrates, can commonly lead to decreased $\mathrm{pH}$, altering ruminal bacteria population and predisposing transition dairy cows to metabolic disorders.

\section{Blood Biomarkers}

During the transition period, dairy cows experience a reduction in energy balance, and lipid mobilization becomes a physiological adaptation mechanism to offset or compensate for the NEB (Contreras and Sordillo, 
2011). Lipid mobilization is associated with hormonal changes around parturition and is characterized by an excessive lipolysis rate over lipogenesis (Bradford et al., 2015). The main products of triglyceride hydrolysis in adipose tissue during lipid mobilization are NEFA, which serve as an alternative energy substrate for most tissues (Contreras and Sordillo, 2011). Blood NEFA reflects the level of NEB in transition dairy cows, and greater NEFA is commonly associated with fatty liver and increased production of ketone bodies (Ingvartsen and Andersen, 2000; Ingvartsen, 2006). During NEB, the liver often exceeds its capacity for oxidizing NEFA, which leads to partial oxidation of NEFA and, consequently, increasing BHB synthesis (Ingvartsen and Andersen, 2000). The BHB is released into the bloodstream and serves as fuel for other tissues (Ingvartsen and Andersen, 2000), and if its blood concentration is elevated enough, it may lead to ketosis (Oetzel, 2004). Minuti et al. (2015) detected lower prepartal NEFA and $\mathrm{BHB}$, followed by a rapid increase after parturition, with the highest concentrations at 10 and 20 DIM.

Inconsistent responses on blood NEFA and BHB have been reported when feeding yeast culture products to transition dairy cows (Yuan et al., 2015a; FaccioDemarco et al., 2019). For instance, Faccio-Demarco et al. (2019) supplemented $28 \mathrm{~g} / \mathrm{d}$ of yeast culture plus enzymatically hydrolyzed yeast of $S$. cerevisiae to transition dairy cows and did not observe differences in NEFA and BHB levels. Transition dairy cows fed with $S$. cerevisiae in combination with 2 Enterococcus strains from -21 to $70 \mathrm{~d}$ relative to parturition had lower postpartal NEFA and BHB concentrations after 8 and 22 DIM, respectively (Nocek et al., 2003). Yuan et al. (2015a) reported that a combination of yeast culture plus enzymatically hydrolyzed yeast at the rate of 0,30 , 60 , and $90 \mathrm{~g} / \mathrm{d}$ from -21 to $42 \mathrm{~d}$ relative to parturition caused an overall postpartal increase in BHB with a numerical increase in NEFA in yeast-fed cows, regardless of the level of supplementation.

A postpartal increase in NEFA in $\mathrm{YC}$ cows was observed in the present study, particularly at 7 DIM (Figure 4). This response was similar to those observed in transition dairy cows diagnosed with subclinical ketosis (Mezzetti et al., 2019) with maximal NEFA and BHB values at 7 DIM. However, the levels of NEFA at $7 \mathrm{DIM}(0.77 \mathrm{mmol} / \mathrm{L}$, respectively $)$ in $\mathrm{YC}$ cows were much lower than those observed by Mezzetti et al. (2019). The latter suggests that the level of lipid mobilization in $\mathrm{YC}$ cows was not conducive to development of subclinical ketosis. In addition, NEFA in YC cows declined more sharply after 7 DIM than in control cows. It is unlikely that lipid metabolism around parturition is directly affected by yeast culture supplementation. Yuan et al. (2015a) reported similar effects on lipid metabolism and partially attributed such effects to numerically lower postpartal DMI. Along the same lines, YC cows in the current study had numerically lower postpartal EB than control, which may partially explain the increase in NEFA.

\section{CONCLUSIONS}

Yeast culture products have been fed to peripartal dairy cows for many years to improve milk yield and milk efficiency. The findings of this study revealed that $\mathrm{YC}$ promoted positive responses in performance, such as milk yield, SCC, and ECM. In the rumen, YC contributed to increased valerate soon after calving. The latter was accompanied by increments in rumen microbiota populations such as cellulolytic and lactic acid-utilizing bacteria. The supply of the yeast culture product and its fermentation metabolites in rumen could be a source of substrates for ruminal bacteria that can promote improvements in fermentable characteristics and optimize the relative abundance of microbial species. Overall, the results describe the potential benefits of supplementing YC during the transition period through early lactation, at least in terms of rumen environment and performance.

\section{ACKNOWLEDGMENTS}

The authors gratefully acknowledge Phibro Animal Health (Teaneck, NJ) for financial support of this research. The authors also thank the South Dakota Agricultural Experiment Station (Brookings, SD), and we gratefully acknowledge the help from all the staff at the Dairy Research and Training Facility at South Dakota State University (Brookings) for animal care and handling. The authors have not stated any conflicts of interest.

\section{REFERENCES}

Abdelmegeid, M. K., A. A. Elolimy, Z. Zhou, V. Lopreiato, J. C. McCann, and J. J. Loor. 2018. Rumen-protected methionine during the peripartal period in dairy cows and its effects on abundance of major species of ruminal bacteria. J. Anim. Sci. Biotechnol. 9:17. https://doi.org/10.1186/s40104-018-0230-8.

Al Ibrahim, R. M., A. K. Kelly, L. O'Grady, V. P. Gath, C. McCarney, and F. J. Mulligan. 2010. The effect of body condition score at calving and supplementation with Saccharomyces cerevisiae on milk production, metabolic status, and rumen fermentation of dairy cows in early lactation. J. Dairy Sci. 93:5318-5328. https:// doi.org/10.3168/jds.2010-3201.

AlZahal, O., L. Dionissopoulos, A. H. Laarman, N. Walker, and B. W. McBride. 2014. Active dry Saccharomyces cerevisiae can alleviate the effect of subacute ruminal acidosis in lactating dairy cows. J. Dairy Sci. 97:7751-7763. https://doi.org/10.3168/jds.2014-8212.

Andries, J. I., F. X. Buysse, D. L. De Brabander, and B. G. Cottyn. 1987. Isoacids in ruminant nutrition: Their role in ruminal and intermediary metabolism and possible influences on performances- 
A review. Anim. Feed Sci. Technol. 18:169-180. https://doi.org/10 $.1016 / 0377-8401(87) 90069-1$.

Bach, A., A. Lopez-Garcia, O. Gonzalez-Recio, G. Elcoso, F. Fabregas, F. Chaucheyras-Durand, and M. Castex. 2019. Changes in the rumen and colon microbiota and effects of live yeast dietary supplementation during the transition from the dry period to lactation of dairy cows. J. Dairy Sci. 102:6180-6198. https://doi.org/10.3168/ jds.2018-16105.

Batistel, F., J. S. Osorio, A. Ferrari, E. Trevisi, M. T. Socha, and J. J. Loor. 2016. Immunometabolic status during the peripartum period is enhanced with supplemental $\mathrm{Zn}, \mathrm{Mn}$, and $\mathrm{Cu}$ from amino acid complexes and Co from Co glucoheptonate. PLoS One 11:e0155804. https://doi.org/10.1371/journal.pone.0155804.

Bradford, B. J., and M. S. Allen. 2004. Milk fat responses to a change in diet fermentability vary by production level in dairy cattle. J. Dairy Sci. 87:3800-3807. https://doi.org/10.3168/jds.S0022 -0302(04)73519-5.

Bradford, B. J., K. Yuan, J. K. Farney, L. K. Mamedova, and A. J. Carpenter. 2015. Invited review: Inflammation during the transition to lactation: New adventures with an old flame. J. Dairy Sci. 98:6631-6650. https://doi.org/10.3168/jds.2015-9683.

Callaway, E. S., and S. A. Martin. 1997. Effects of a Saccharomyces cerevisiae culture on ruminal bacteria that utilize lactate and digest cellulose. J. Dairy Sci. 80:2035-2044. https://doi.org/10 .3168/jds.S0022-0302(97)76148-4.

Chaney, A. L., and E. P. Marbach. 1962. Modified reagents for determination of urea and ammonia. Clin. Chem. 8:130-132. https:// doi.org/10.1093/clinchem/8.2.130.

Chaucheyras-Durand, F., N. D. Walker, and A. Bach. 2008. Effects of active dry yeasts on the rumen microbial ecosystem: Past, present and future. Anim. Feed Sci. Technol. 145:5-26. https://doi.org/10 .1016/j.anifeedsci.2007.04.019.

Contreras, G. A., and L. M. Sordillo. 2011. Lipid mobilization and inflammatory responses during the transition period of dairy cows. Comp. Immunol. Microbiol. Infect. Dis. 34:281-289. https://doi .org/10.1016/j.cimid.2011.01.004.

Dann, H. M., J. K. Drackley, G. C. McCoy, M. F. Hutjens, and J. E. Garrett. 2000. Effects of yeast culture (Saccharomyces cerevisiae) on prepartum intake and postpartum intake and milk production of Jersey cows. J. Dairy Sci. 83:123-127. https://doi.org/10.3168/ jds.S0022-0302(00)74863-6.

Dawson, K. A., K. E. Newman, and J. A. Boling. 1990. Effects of microbial supplements containing live yeast and lactobacilli on roughage-fed ruminal microbial activities. J. Anim. Sci. 68:33923398. https://doi.org/10.2527/1990.68103392x.

Desnoyers, M., S. Giger-Reverdin, G. Bertin, C. Duvaux-Ponter, and D. Sauvant. 2009. Meta-analysis of the influence of Saccharomyces cerevisiae supplementation on ruminal parameters and milk production of ruminants. J. Dairy Sci. 92:1620-1632. https://doi.org/ 10.3168/jds.2008-1414.

Dias, A. L. G., J. A. Freitas, B. Micai, R. A. Azevedo, L. F. Greco, and J. E. P. Santos. 2018. Effect of supplemental yeast culture and dietary starch content on rumen fermentation and digestion in dairy cows. J. Dairy Sci. 101:201-221. https://doi.org/10.3168/ jds.2017-13241.

Drackley, J. K. 1999. Biology of dairy cows during the transition period: The final frontier? J. Dairy Sci. 82:2259-2273. https://doi .org/10.3168/jds.S0022-0302(99)75474-3.

Elolimy, A. A., J. M. Arroyo, F. Batistel, M. A. Iakiviak, and J. J. Loor. 2018. Association of residual feed intake with abundance of ruminal bacteria and biopolymer hydrolyzing enzyme activities during the peripartal period and early lactation in Holstein dairy cows. J. Anim. Sci. Biotechnol. 9:43. https://doi.org/10.1186/ s40104-018-0258-9.

Faccio-Demarco, C., T. Mumbach, V. Oliveira-de-Freitas, R. Fraga e Silva-Raimondo, F. Medeiros-Gonçalves, M. Nunes-Corrêa, F. A. Burkert-Del Pino, H. Mendonca-Nunes-Ribeiro Filho, and C. Cassal-Brauner. 2019. Effect of yeast products supplementation during transition period on metabolic profile and milk production in dairy cows. Trop. Anim. Health Prod. 51:2193-2201. https:// doi.org/10.1007/s11250-019-01933-y.
Garcia Diaz, T., A. Ferriani Branco, F. A. Jacovaci, C. Cabreira Jobim, J. L. Pratti Daniel, A. V. Iank Bueno, and M. Goncalves Ribeiro. 2018. Use of live yeast and mannan-oligosaccharides in grain-based diets for cattle: Ruminal parameters, nutrient digestibility, and inflammatory response. PLoS One 13:e0207127. https: //doi.org/10.1371/journal.pone.0207127.

Ghazanfar, S., N. Khalid, I. Ahmed, and M. Imran. 2017. Probiotic yeast: Mode of action and its effects on ruminant nutrition. Chapter 8 in Yeast: Industrial Applications. InTech Open.

Grazziotin, R. C. B., J. Halfen, F. Rosa, E. Schmitt, J. L. Anderson, V. Ballard, and J. S. Osorio. 2020. Altered rumen fermentation patterns in lactating dairy cows supplemented with phytochemicals improve milk production and efficiency. J. Dairy Sci. 103:301312. https://doi.org/10.3168/jds.2019-16996.

Harrison, G. A., R. W. Hemken, K. A. Dawson, R. J. Harmon, and K. B. Barker. 1988. Influence of addition of yeast culture supplement to diets of lactating cows on ruminal fermentation and microbial populations. J. Dairy Sci. 71:2967-2975. https://doi.org/10.3168/ jds.S0022-0302(88)79894-X.

Henderson, G., F. Cox, S. Kittelmann, V. H. Miri, M. Zethof, S. J. Noel, G. C. Waghorn, and P. H. Janssen. 2013. Effect of DNA extraction methods and sampling techniques on the apparent structure of cow and sheep rumen microbial communities. PLoS One 8:e74787. https://doi.org/10.1371/journal.pone.0074787.

Hutjens, M. F. 2010. Benchmarking your feed efficiency, feed costs, and income over feed cost. WCDS Advances in Dairy Technology. $22: 3-10$.

Ingvartsen, K. L. 2006. Feeding- and management-related diseases in the transition cow. Anim. Feed Sci. Technol. 126:175-213. https:/ /doi.org/10.1016/j.anifeedsci.2005.08.003.

Ingvartsen, K. L., and J. B. Andersen. 2000. Integration of metabolism and intake regulation: A review focusing on periparturient animals. J. Dairy Sci. 83:1573-1597. https://doi.org/10.3168/jds .S0022-0302(00)75029-6.

Jacometo, C. B., Z. Zhou, D. Luchini, E. Trevisi, M. N. Correa, and J. J. Loor. 2016. Maternal rumen-protected methionine supplementation and its effect on blood and liver biomarkers of energy metabolism, inflammation, and oxidative stress in neonatal Holstein calves. J. Dairy Sci. 99:6753-6763. https://doi.org/10.3168/ jds.2016-11018.

Jensen, G. S., K. M. Patterson, and I. Yoon. 2008. Yeast culture has anti-inflammatory effects and specifically activates NK cells. Comp. Immunol. Microbiol. Infect. Dis. 31:487-500. https://doi .org/10.1016/j.cimid.2007.08.005

Jiang, Y., I. M. Ogunade, K. G. Arriola, M. Qi, D. Vyas, C. R. Staples, and A. T. Adesogan. 2017. Effects of the dose and viability of Saccharomyces cerevisiae. 2. Ruminal fermentation, performance of lactating dairy cows, and correlations between ruminal bacteria abundance and performance measures. J. Dairy Sci. 100:81028118. https://doi.org/10.3168/jds.2016-12371.

Jiao, P., C. Wei, Y. Sun, X. Xie, Y. Zhang, S. Wang, G. Hu, O. AlZahal, and W. Yang. 2019. Screening of live yeast and yeast derivatives for their impact of strain and dose on in vitro ruminal fermentation and microbial profiles with varying media $\mathrm{pH}$ levels in high-forage beef cattle diet. J. Sci. Food Agric. 99:6751-6760. https://doi.org/10.1002/jsfa.9957.

Khafipour, E., S. Li, J. C. Plaizier, and D. O. Krause. 2009. Rumen microbiome composition determined using two nutritional models of subacute ruminal acidosis. Appl. Environ. Microbiol. 75:71157124. https://doi.org/10.1128/AEM.00739-09.

Knoblock, C. E., W. Shi, I. Yoon, and M. Oba. 2019. Effects of supplementing a Saccharomyces cerevisiae fermentation product during the periparturient period on the immune response of dairy cows fed fresh diets differing in starch content. J. Dairy Sci. 102:61996209. https://doi.org/10.3168/jds.2018-16224.

Kumprechtová, D., J. Illek, C. Julien, P. Homolka, F. Jancik, and E. Auclair. 2019. Effect of live yeast (Saccharomyces cerevisiae) supplementation on rumen fermentation and metabolic profile of dairy cows in early lactation. J. Anim. Physiol. Anim. Nutr. (Berl.) 103:447-455. https://doi.org/10.1111/jpn.13048. 
Lascano, G. J., and A. J. Heinrichs. 2009. Rumen fermentation pattern of dairy heifers fed restricted amounts of low, medium, and high concentrate diets without and with yeast culture. Livest. Sci. 124:48-57. https://doi.org/10.1016/j.livsci.2008.12.007.

Lima, F. S., G. Oikonomou, S. F. Lima, M. L. Bicalho, E. K. Ganda, J. C. de Oliveira Filho, G. Lorenzo, P. Trojacanec, and R. C. Bicalhoa. 2015. Prepartum and postpartum rumen fluid microbiomes: Characterization and correlation with production traits in dairy cows. Appl. Environ. Microbiol. 81:1327-1337. https://doi.org/10 .1128/AEM.03138-14.

Liu, Q., C. Wang, Y. X. Huang, K. H. Dong, W. Z. Yang, S. L. Zhang, and H. Wang. 2009. Effects of isovalerate on ruminal fermentation, urinary excretion of purine derivatives and digestibility in steers. J. Anim. Physiol. Anim. Nutr. (Berl.) 93:716-725. https://doi.org/ 10.1111/j.1439-0396.2008.00861.x.

Longuski, R. A., Y. Ying, and M. S. Allen. 2009. Yeast culture supplementation prevented milk fat depression by a short-term dietary challenge with fermentable starch. J. Dairy Sci. 92:160-167. https: //doi.org/10.3168/jds.2008-0990.

Lopreiato, V., M. Mezzetti, L. Cattaneo, G. Ferronato, A. Minuti, and E. Trevisi. 2020. Role of nutraceuticals during the transition period of dairy cows: A review. J. Anim. Sci. Biotechnol. 11:96. https://doi.org/10.1186/s40104-020-00501-x.

Meller, R. A., B. A. Wenner, J. Ashworth, A. M. Gehman, J. Lakritz, and J. L. Firkins. 2019. Potential roles of nitrate and live yeast culture in suppressing methane emission and influencing ruminal fermentation, digestibility, and milk production in lactating Jersey cows. J. Dairy Sci. 102:6144-6156.

Mezzetti, M., A. Minuti, F. Piccioli-Cappelli, M. Amadori, M. Bionaz, and E. Trevisi. 2019. The role of altered immune function during the dry period in promoting the development of subclinical ketosis in early lactation. J. Dairy Sci. 102:9241-9258. https://doi.org/10 $.3168 / j d s .2019-16497$

Minuti, A., A. Palladino, M. J. Khan, S. Alqarni, A. Agrawal, F. Piccioli-Capelli, F. Hidalgo, F. C. Cardoso, E. Trevisi, and J. J. Loor. 2015. Abundance of ruminal bacteria, epithelial gene expression, and systemic biomarkers of metabolism and inflammation are altered during the peripartal period in dairy cows. J. Dairy Sci. 98:8940-8951. https://doi.org/10.3168/jds.2015-9722.

Mullins, C. R., L. K. Mamedova, A. J. Carpenter, Y. Ying, M. S. Allen, I. Yoon, and B. J. Bradford. 2013. Analysis of rumen microbial populations in lactating dairy cattle fed diets varying in carbohydrate profiles and Saccharomyces cerevisiae fermentation product. J. Dairy Sci. 96:5872-5881. https://doi.org/10.3168/jds .2013-6775.

Nocek, J. E., M. G. Holt, and J. Oppy. 2011. Effects of supplementation with yeast culture and enzymatically hydrolyzed yeast on performance of early lactation dairy cattle. J. Dairy Sci. 94:40464056. https://doi.org/10.3168/jds.2011-4277.

Nocek, J. E., W. P. Kautz, J. A. Z. Leedle, and E. Block. 2003. Directfed microbial supplementation on the performance of dairy cattle during the transition period. J. Dairy Sci. 86:331-335. https://doi .org/10.3168/jds.S0022-0302(03)73610-8.

NRC. 2001. Nutrient Requirements of Dairy Cattle. 7th rev. ed. Natl. Acad. Press.

Oetzel, G. R. 2004. Monitoring and testing dairy herds for metabolic disease. Vet. Clin. North Am. Food Anim. Pract. 20:651-674. https://doi.org/10.1016/j.cvfa.2004.06.006.

Ogunade, I. M., J. Lay, K. Andries, C. J. McManus, and F. Bebe. 2019. Effects of live yeast on differential genetic and functional attributes of rumen microbiota in beef cattle. J. Anim. Sci. Biotechnol. 10:68. https://doi.org/10.1186/s40104-019-0378-x.

Olagaray, K. E., S. E. Sivinski, B. A. Saylor, L. K. Mamedova, J. A. Sauls-Hiesterman, I. Yoon, and B. J. Bradford. 2019. Effect of Saccharomyces cerevisiae fermentation product on feed intake parameters, lactation performance, and metabolism of transition dairy cattle. J. Dairy Sci. 102:8092-8107. https://doi.org/10.3168/ jds.2019-16315.

Perdomo, M. C., R. S. Marsola, M. G. Favoreto, A. Adesogan, C. R. Staples, and J. E. P. Santos. 2020. Effects of feeding live yeast at 2 dosages on performance and feeding behavior of dairy cows under heat stress. J. Dairy Sci. 103:325-339. https://doi.org/10.3168/jds .2019-17303.

Persson Waller, K., U. Grönlund, and A. Johannisson. 2003. Intramammary infusion of 31,3 -glucan for prevention and treatment of Staphylococcus aureus mastitis. J. Vet. Med. 50:121-127. https:// doi.org/10.1046/j.1439-0450.2003.00630.x.

Pinloche, E., N. McEwan, J. P. Marden, C. Bayourthe, E. Auclair, and C. J. Newbold. 2013. The effects of a probiotic yeast on the bacterial diversity and population structure in the rumen of cattle. PLoS One 8:e67824. https://doi.org/10.1371/journal.pone.0067824.

Poppy, G. D., A. R. Rabiee, I. J. Lean, W. K. Sanchez, K. L. Dorton, and P. S. Morley. 2012. A meta-analysis of the effects of feeding yeast culture produced by anaerobic fermentation of Saccharomyces cerevisiae on milk production of lactating dairy cows. J. Dairy Sci. 95:6027-6041. https://doi.org/10.3168/jds.2012-5577.

Proust, L., E. Haudebourg, A. Sourabie, M. Pedersen, I. Besancon, V. Monnet, and V. Juillard. 2020. Multi-omics approach reveals how yeast extract peptides shape Streptococcus thermophilus metabolism. Appl. Environ. Microbiol. 86:e01446-20. https://doi.org/10 .1128/AEM.01446-20.

Puniya, A. K., R. Singh, and D. N. Kamra. 2015. Rumen Microbiology: From Evolution to Revolution. Springer.

Robinson, P. H., and L. J. Erasmus. 2009. Effects of analyzable diet components on responses of lactating dairy cows to Saccharomyces cerevisiae based yeast products: A systematic review of the literature. Anim. Feed Sci. Technol. 149:185-198. https://doi.org/10 .1016/j.anifeedsci.2008.10.003.

Robinson, P. H., and J. E. Garrett. 1999. Effect of yeast culture (Saccharomyces cerevisiae) on adaptation of cows to postpartum diets and on lactational performance. J. Anim. Sci. 77:988-999. https:/ /doi.org/10.2527/1999.774988x.

Roche, J. R., A. W. Bell, T. R. Overton, and J. J. Loor. 2013. Nutritional management of the transition cow in the 21st century- $\mathrm{A}$ paradigm shift in thinking. Anim. Prod. Sci. 53:1000-1023. https: //doi.org/10.1071/AN12293.

Russell, J. B. 2002. Rumen Microbiology and Its Role in Ruminant Nutrition. James B. Russell.

Shabat, S. K., G. Sasson, A. Doron-Faigenboim, T. Durman, S. Yaacoby, M. E. Berg Miller, B. A. White, N. Shterzer, and I. Mizrahi. 2016. Specific microbiome-dependent mechanisms underlie the energy harvest efficiency of ruminants. ISME J. 10:2958-2972. https: //doi.org/10.1038/ismej.2016.62.

Shi, W., C. E. Knoblock, K. V. Murphy, T. C. Bruinje, I. Yoon, D. J. Ambrose, and M. Oba. 2019a. Effects of supplementing a Saccharomyces cerevisiae fermentation product during the periparturient period on performance of dairy cows fed fresh diets differing in starch content. J. Dairy Sci. 102:3082-3096. https://doi.org/10 .3168/jds.2018-15307.

Shi, W., C. E. Knoblock, I. Yoon, and M. Oba. 2019b. Effects of supplementing a Saccharomyces cerevisiae fermentation product during the transition period on rumen fermentation of dairy cows fed fresh diets differing in starch content. J. Dairy Sci. 102:9943-9955. https://doi.org/10.3168/jds.2019-16671.

Shurson, G. C. 2018. Yeast and yeast derivatives in feed additives and ingredients: Sources, characteristics, animal responses, and quantification methods. Anim. Feed Sci. Technol. 235:60-76. https://doi .org/10.1016/j.anifeedsci.2017.11.010.

Stefenoni, H., J. H. Harrison, A. Adams-Progar, and E. Block. 2020 Effect of enzymatically hydrolyzed yeast on health and performance of transition dairy cattle. J. Dairy Sci. 103:1541-1552. https://doi.org/10.3168/jds.2019-17350.

Stevenson, D. M., and P. J. Weimer. 2007. Dominance of Prevotella and low abundance of classical ruminal bacterial species in the bovine rumen revealed by relative quantification real-time PCR. Appl. Microbiol. Biotechnol. 75:165-174. https://doi.org/10.1007/ s00253-006-0802-y.

Trevisi, E., M. Amadori, S. Cogrossi, E. Razzuoli, and G. Bertoni. 2012. Metabolic stress and inflammatory response in high-yielding, periparturient dairy cows. Res. Vet. Sci. 93:695-704. https://doi .org/10.1016/j.rvsc.2011.11.008. 
Trevisi, E., and A. Minuti. 2018. Assessment of the innate immune response in the periparturient cow. Res. Vet. Sci. 116:47-54. https: //doi.org/10.1016/j.rvsc.2017.12.001.

Weimer, P. J., and G. N. Moen. 2013. Quantitative analysis of growth and volatile fatty acid production by the anaerobic ruminal bacterium Megasphaera elsdenii T81. Appl. Microbiol. Biotechnol. 97:4075-4081. https://doi.org/10.1007/s00253-012-4645-4.

Won, M. Y., L. B. Oyama, S. J. Courtney, C. J. Creevey, and S. A. Huws. 2020. Can rumen bacteria communicate to each other? Microbiome 8:23. https://doi.org/10.1186/s40168-020-00796-y.

Yuan, K., T. Liang, M. B. Muckey, L. G. Mendonca, L. E. Hulbert, C. C. Elrod, and B. J. Bradford. 2015a. Yeast product supplementation modulated feeding behavior and metabolism in transition dairy cows. J. Dairy Sci. 98:532-540. https://doi.org/10.3168/jds .2014-8468

Yuan, K., L. G. Mendonca, L. E. Hulbert, L. K. Mamedova, M. B. Muckey, Y. Shen, C. C. Elrod, and B. J. Bradford. 2015b. Yeast product supplementation modulated humoral and mucosal immunity and uterine inflammatory signals in transition dairy cows. J. Dairy Sci. 98:3236-3246. https://doi.org/10.3168/jds.2014-8469.

Zaworski, E. M., C. M. Shriver-Munsch, N. A. Fadden, W. K. Sanchez, I. Yoon, and G. Bobe. 2014. Effects of feeding various dosages of Saccharomyces cerevisiae fermentation product in transition dairy cows. J. Dairy Sci. 97:3081-3098. https://doi.org/10.3168/jds.2013 -7692 .

Zeineldin, M., R. Barakat, A. Elolimy, A. Z. M. Salem, M. M. Y. Elghandour, and J. C. Monroy. 2018. Synergetic action between the rumen microbiota and bovine health. Microb. Pathog. 124:106115. https://doi.org/10.1016/j.micpath.2018.08.038.

Zhu, W., Z. Wei, N. Xu, F. Yang, I. Yoon, Y. Chung, J. Liu, and J. Wang. 2017. Effects of Saccharomyces cerevisiae fermentation products on performance and rumen fermentation and microbiota in dairy cows fed a diet containing low quality forage. J. Anim. Sci. Biotechnol. 8:36. https://doi.org/10.1186/s40104-017-0167-3.

\section{ORCIDS}

N. A. Carpinelli @ https://orcid.org/0000-0003-1208-8671

J. Halfen (ㅇ https://orcid.org/0000-0002-1317-1322

E. Trevisi ๑ https://orcid.org/0000-0003-1644-1911

J. D. Chapman $\odot$ https://orcid.org/0000-0002-3412-6432

E. D. Sharman @ \ttps://orcid.org/0000-0002-5776-5819

J. L. Anderson @ https://orcid.org/0000-0001-7590-0749

J. S. Osorio @ \ttps://orcid.org/0000-0001-6192-0917 